\title{
COLLECTIVE LABOR AGREEMENTS IN THE COURTS
}

\author{
BY T. RICHARD WITMER $\dagger$
}

"Contract" is a word of large and varied social import. Hand in hand under its patronage march agreements to marry and yellow-dog contracts, entirely personal contracts of suretyship and mass production life insurance policies, agreements with the Federal government to restrict acreage and agreements by employees not to compete with employers after leaving the job, contracts for the sale of goods or for personal services and the supposititious agreements existing between the stockholders of one of our modern corporate giants and the corporation, between the corporation and the state, between the state and the stoclholders, and, for good measure, among the stockholders themselves.

Any formula which can tie all of these and dozèns more into a single concept must be very much of an abstraction. It is. The reality comes out only when, and only to the extent that, courts and legislatures look at the individual bargain in question and read it not as $a$ contract but as one type of contract. Though the basic formula-the words that are used-may remain the same, the application of the formula becomes many-hued. Is this an agreement between employer and employee? Then it is to be construed strongly against the employer. Is it a contract of insurance? Then the legislature has said that certain clauses must appear in it or, failing to make such an appearance, shall be read there in any event. Is it an agreement between husband and wife? Perhaps it was not "meant" to be enforced in the courts. Is it a contract for the sale of goods? Then in case of breach we leave the plaintiff to his action for damages. Or is it for the sale of land? Then specific performance is open to him. So one can go down the line picking one's way through the precedents, finding differing remedies for differing types of contract (some conditioned only, or too much, by history; others showing signs of real contemporary social intuition), feeling the lean of the court one way or another, hearing it sometimes avow such learnings explicitly, rarely disturbing the age-old familiar words, occasionally doing so.

It is in terms of contract, then, that the collective bargain reaches the courts when it reaches them at all. ${ }^{1}$ No other formula has appeared

$\div$ Assistant Professor of Law, Yale Law School.

1. For previous periodical literature on this subject in general, sce Anderson, Collective Bargaining Agreements (1936) 15 ORE. L. Rev. 229; Christenson, Legally Enforecable Interests in Ancrican Labor Union Working Agreenents (1933) 9 I:n. L. J. 69; Duguit, Collective Acts as Distinguished from Contracts (1918) 27 YNLE L. J. 753; Fuchs, Collective Labor Agrecments ir American Law (1925) 10 Sr. Lours L. Rev. 1; Fuchs, Collective Labor Agreements Under Administratize Regulation of Employment (1935) 35 Coc. L. Rev. 493; Hamilton, Individual Rights Arising from Collectize Labor 
ready-made for the purpose. No other formula gives so close a fit or needs so little cutting and patching to give a tolerably good fit. But cutting and patching there must be if the fit is to be really good. For, looked at in the large, the collective bargain is like nothing that the law has ever had to deal with before. ${ }^{2}$ If, from some particular angle, it may resemble something else with which the courts are more familiar, its total effect is considerably different from any of them. Thus, though one could compare it with, say, a group insurance contract if one viewed it only as an agreement between a multiplicity of workers on the one side and a single employer on the other, one has also to compare it with a cooperative marketing contract if it is looked at chiefly as a device for preventing competition among the union members. One could compare it with a minimum wage statute if one were interested in it as a device for fixing a figure below which employers will not be permitted to go in hiring people as well as for limiting competition among employees, but one might also compare it with the agreements made between any local telephone company and its customers if one is thinking of the union as a monopolizer of labor. If one looks at it as a device for preventing competition among common purchasers of the union's only marketable product, labor, one will compare it with contemporary fair trade statutes and contracts made under their authority, but if one's interest and attitude. is that of a supposedly typical employer one almost immediately begins to think of the manner of its formation in terms of "coercion", "duress" and similar words of tort-content.

If none of the analogies that have been adduced fits the picture completely, it would be strange if such an all-inclusive notion as that conjured up by the mere word "contract" would do so automatically. That contract doctrine can be made to cover it, there is little doubt. It would be odd if a doctrine which already covers so great a variety of human transactions could not be revamped sufficiently to embrace still another. But it would be still more odd if a doctrine moulded in feudal society, adapted to commercial life, and only recently encountering industrial society, would give precisely the desired results immediately. It is this process of adaptaltion that we are going through today. Fifty years ago probably not one

Contracts (1938) 3 Mo. L. Rev. 252; Mason, Organized Labor as Party Plainliff in Injunction Cases (1930) 30 CoL. L. Rev. 466; Rice, Collectiv' Labor Agrecments in American Law (1931) 44 Hanv. L. Rev. 572; Witte, Labor's Resort to Injunclions (1930) 39 Yale L. J. 374; Comments (1924) 24 Col. L. Rev. 409, (1931) 31 Cot. L. Rev. 1156, (1930) 16 CoRn. L. Q. 96, (1938) 51 HaRv. L. Rev. 520, (1934) 18 Mako. L. Rev. 251, (1932) 41 YaLe L. J. 1221.

2. This statement, I think, is equally true whether one regards the collective bargain as "ultimately" nothing more than a truce along a particular front in a class struggle, or as the formal constitution of a system of industrial democracy, or as the final expression of business unionism. With such "ultimates" there is no concern herc. Nor is there concern with whether the collective bargain is "really" a contract. See Duguit, (1918) 27 Yale L. J. 753, 763 (arguing that it is not). 
court in the country had heard of a collective bargain in its official ear. Twenty years ago the debate was whether collective bargains ought to be enforced. ${ }^{3}$ Today the question is how they shall be enforced, by whom they shall be enforced, to what effect they shall be enforced, and how far all the collateral doctrine that clusters about the abstract notion of an abstract contract between an abstract $A$ and an abstract $B$ shall be carried over and applied to the newest of the progeny.

If it is important that the collective bargain be characterized in its social content, it is equally important that such a characterization recognize that "collective bargain" is itself a broad term covering a multitude of socially different cases. A collective agreement between the General Electric Company and its workers at Schenectady will be more important in regulating the daily life of the city than almost any ordinance the city fathers could adopt; an agreement between the owners of a theatre in Hattiesburg, Miss.-population 18,000-and its employees will have no such consequence. A collective agreement between the United Mine Workers and the operators of the central competitive field may affect the price of coal as much as a ruling by the Interstate Commerce Commission on freight rates; an agreement between the employees of the Hamilton Watch Company and the corporation will be of comparatively slight significance except to the immediate parties. Organization of the textile workers of the country, followed by collective agreements, will put the Federal wages and hours bill in the shade, silence, to the extent that cheap labor is responsible for the migration, those New Englanders who look at the departure of industry from their bailiwicks with horror, transfer the setting of differentials in wage rates from a public body to a "private" group and obviate the constitutional qualms of those who see a threat to states' rights in the legislation; organization of the linoleum workers in the United States will mean little more than a lessening of competition at the wage level within an oligopolistic industry. Collective bargaining in the steel towns of the Monongahela Valley will do a good deal towards restoring democracy to local government; collective bargaining by the grocery clerks of the same towns will do nothing of the sort. An agreement between a solvent Amoskeag Cotton Mills and its employees ought, in not too long a run, to give the latter some standing in a bankruptcy court alongside of or in opposition to the bondholders' protective committees; an agreement in an already defunct or decadent industry will at best postpone the effects of rigor mortis industrialis on innocent third parties.

One can not, then, hope to gather up within the mere words "collective bargain" all varieties of collective bargains any more than one can comprehend within the word "corporation" all the social significance its

3. See Christenson, (1933) 9 Irv. L. J. 69, 70; Fuchs, (1925) 10 Sr. Lours L. REv. 1, 7. 
numerous species have in practice. One can, however,-summarizing what has already been said and adding a little-set down two or three of its distinguishing characteristics: It will, in any case, lessen or eliminate competition locally among the workers in a given plant. If the industry is nation-wide and the collective bargaining system is of equal expanse, it will serve in that industry some of the functions that a minimum wage statute serves, viz., elimination of competition at the wage level and provision for some minimum standard of living and working for those employed in it. It will be in most cases a bargain made unwillingly by one side, a bargain made only when there appears to be no possibility of avoiding it save at the cost of a long fight; it will, by the same tolen, be a bargain not to be renewed unless there is the same pressure." It will be, for the other side, a vital necessity if the purposes of unionism are to be served at all. It will be a bargain in brief made without readily available alternatives for either side-none for the employer unless he is willing to fight; none for the union because, until it has the whole industry signed up, it faces competition not only from non-members who offer to work for less on jobs now controlled by the union but also from nonmembers working in unorganized plants whose products compete with those of plants in which the union does prevail.

There is no compelling reason why collective bargains should be enforced by courts or other public agencies. Though a few judges have

4. For an indication of the extent to which the collective bargaining system was sabotaged in the early 1920 's, see the earlier volumes of LAW AND LAzoR. Case after case follows the pattern: "The plaintiff had a collective agreement with the $\boldsymbol{X}$ union which expired on May 1, 1922. Thoroughly dissatisfied with it, he decided not to renew it and announced this to his employees. On May 1, they went on strike and picketed the plant. The plaintiff sought an injunction against this violence and intimidation . . ."

5. No attempt is made hereafter to deal with methods of enforcement, as, for example, arbitration, other than those provided by public agencies. See Oliver, The Arlintration of Labor Disputes (1934) 83 U. OF PA. L. REv. 206; Phillips, The Function of Arbitration in the Settlcment of Industrial Disputes (1933) 33 CoL. L. Rux. 1360; Tongue, The Development of Industrial Conciliation and Arbitration Under Trade Aarcements (1938) 17 ORE. L. Rev. 263; see note 45 infra. Nor is specific reference made hereafter to the function of the National Labor Relations Board as a contract-cnforcing agency. Though breach of an agreement does not per sc give the employees a catuse of action against the employer before the Board, a refusal by an employer to bargain before he commits the breach has been held by the Board to be an unfair labor practice. Matter of Chicago Defender, 1 N. L. R. B. (old) 119, 121 (1934); Matter of Lotis Hornick \& Co., 2 N. L. R. B. 983, 994 (1937). The Board has also held that the purpose of the Act requires that the employer discuss changes in the terms of the agreement proposed by the union and that a refusal to discuss such changes will be an unfair labor practice even though the refusal is followed by a breach of the agreement on the part of the union. Matter of The Sands Manufacturing Co., 1 N. L. R. B. 546, 562 (1936), order set aside, N. L. R. B. v. Sands Manufacturing Co., 96 F. (2d) 721 (C. C. A. 6th, 1938), cert. granted, 83 Sup. Ct. 10 (1938). Though the breach may leave the union open to an action for damages or for an injunction, this does not deprive the Board of its jurisdiction. In view of the stated aim of the Act-the maintenance of a free flow of commerce unimpeded by industrial strife-it would be hard to find fault with this policy. 
suggested that unless they enforce the bargain it would be a useless and meaningless thing, ${ }^{6}$ this must be taken largely as a clearing of the throat in the face of a new situation, as a justification for embarking on a new and strange voyage. In commercial life, breach of contract is normally the occasion for nothing at all ; it is taken for granted that, for the most part, no attention will be paid to breaches. Probably the next most frequent occurrence is a resort to a negative variety of self-help, typified by the If-he-doesn't-want-to-live-up-to-his-agreements,-I-simply-won'tdeal-with-him-anymore attitude. Only in desperation is there a resort to the courts.

Pari passu the chances are that even if courts did not see their way clear to enforce collective bargains their status in actual life would be much what it is today. Most of them would be lived up to even if the parties knew that there was no legal sanction behind them. The petty breaches would be ignored by both sides. The major breaches, after strong and repeated protests failed, would be solved on the part of the union by striking and on the part of the employers by an announced refusal to deal with an "irresponsible" body and a lockout." An optimist might be tempted to say, then, that resort to the courts to remedy breaches of collective agreements is a sign of increasing good will and confidence, of a willingness to substitute orderly means for the more turbulent strike or lockout. A cynic might be tempted to say that it is only when it looks as though these latter methods will fail or after they have failed that anyone ever asks the help of a stranger to the agreement-the court. ${ }^{8}$ Strangers the courts are today, but strangers they are not remaining. For an increasingly large number of possible controversies are being settled in this way.

I.

As a matter of fact there has been comparatively little dispute in the courts as to whether collective agreements are enforceable. ${ }^{0}$ Either it has been taken for granted that they are or the objections to enforcement have been brushed aside with but little discussion. When the suit was brought by the union, however, some of the earlier cases refused enforcement on the ground that the wrong remedy had been asked for. Such, for instance,

6. See Mississippi Theatres Corp. v. Hattiesburg Local, No. 615, 174 Miss. 439, 447, 164 So. 887, 890 (1936) ; Leveranz v. Cleveland Home Brewing Co., 24 Ohio N. P. (x. s.) 193, 199 (1922). But see Young v. Canadian Northern Ry. [1931] A. C. 83, 89 (P. C.) ; Bancroft v. Canadian Pac. Ry., 30 Mlanitoba 401, 408 (1920).

7. On the law of self-help in these labor cases, see notes 51 fr. infro.

8. See David Adler \& Sons Co. v. Mfaglio, 200 Wis. 153, 158, 228 N. W. 123, 125 (1929). See note 52, infra.

9. It is assumed hereafter that some means-generally statutory-is provided for suits by and against unincorporated unions. 
was the case of Stone Cleaning and Pointing Union v. Russell, ${ }^{\mathbf{1 0}}$ in which the plaintiff union, attempting to turn Lumley $v$. Wagner ${ }^{11}$ around backwards, asked that the defendant employer be restrained from employing, contrary to the agreement, workers who were not members of the Union. The injunction was refused:

"The employment in question, so far from being unique and extraordinaty, appears to be one of a very uniform and established character. The plaintiff, if it has any cause of action, will have an adequate remedy of law, just as would any other employee wrongfully discharged. It will be possible for it to show the amount of services of the kind specified in the contract rendered to defendant by others than its members, and which its members might have rendered, and the consequent damages, if any." 12

Not only did the court fail to see that the test to be applied is the uniqueness of the employer rather than the uniqueness of the kind of work done by the plaintiff's members-though, in this respect, the decision would probably not have been any different-but it also misconceived the extent and purpose of the collective bargain. It talked as though a union sold labor over the counter. It forgot that to require the union to forego suit until the term of the agreement had run out would mean breaking down the industrial standards established by the bargain and that suits week by week or month by month, even if they escaped condemnation on other scores, would be a practical impossibility. It failed to realize that the union in its collective capacity had an interest in the agreement apart from the particular wages that its members might collect. ${ }^{13}$ And it assumed wrongly that an orderly distribution of the proceeds of a damage suit could be made by the union to its members, ${ }^{14}$ disregarding, so far as appears here, any possibility that while the defendant may have

10. 38 Misc. 513, 77 N. Y. Supp. 1049 (Sup. Ct. 1902) ; Schwartz v. Wayne Circuit Judge, 217 Mich. 384, 186 N. W. 522, Schwartz v. Cigar Makers International Union, 219 Mich. 589, 189 N. W. 55 (1922). For a summary and extensive quotations from the lower court's excellent opinion in the Michigan cases see 4 LAW AND LABOR 216 (1922). Cf. Adelman v. Universal Fur Dressing Co., 116 N. J. Eq. 511, 513, 174 Atl. 523, 524 (1934), denying similar relief on a preliminary hearing because the injunction would require defendant to discharge its present workers when it is not clear that plaintiff's allegations are correct.

11. 1 De G. M. \& G. 604 (Ch. App. 1852).

12. 38 Misc. 513, 77 N. Y. Supp. 1049 (Sup. Ct., 1902).

13. See Goldman v. Cohen, 222 App. Div. 631, 633, 227 N. Y. Supp. 311, 314 (1st Dep't 1928); Leveranz v. Cleveland Home Brewing Co., 24 Ohio N. P. (N. s.) 193, 198, 199 (1922).

14. See Harper v. Local Union No. 120, International Brotherhood of Electrical Workers, 48 S. W. (2d) 1033, 1042 (Tex. Civ. App. 1932) ("no criterion of practical application for ascertaining the damages that would flow from breach of the collective agreement"). 
had only 50 jobs to give out the union may have had 100 unemployed members.

So far as New York is concerned, at any rate, this case has completely gone by the boards since the decision in Schlesinger 2. Quinlo. ${ }^{15}$ By a fortunate mischance the appellate court allowed this case to appear to be broader than it was in fact and opened the way for the lower New York courts and for the courts of other states to misconceive its scope. In the lower court-before Mr. Justice, now Senator, Wagner-it was treated not as a suit to enjoin breach of a collective agreement but as a suit to enjoin the defendants from forcing others to break the agreement. ${ }^{10}$ Its background was a trade agreement entered into between the International Ladies Garment Workers Union on the one side and an employers' association on the other. Originally made in 1919, it was modified in 1921 after a dispute over wages and other conditions of work and the appointment of a gubernatorial commission. While the union and the association were conferring on further possible changes to be made in the agreement, the association resolved to change from a week-work to a piecework basis of production, to reduce wages and to increase hours. It resolved, moreover, that these changes should be made during the term of the agreement. An attempt to put them in force was met by a strike and by this action. The judgment of the lower court granting the injunction requested was affirmed by a divided Appellate Division. To the defendant's contention that such an injunction amounted to an order of specific performance of a contract for personal services, the court replied that it was not a contract for personal services at all but rather an agreement between two organizations, ${ }^{17}$ each of which had disciplinary power over its members, and that the decree required only that that disciplinary authority be exercised. ${ }^{18}$

Not only has Schlesinger v. Quinto let loose a comparative flood of injunctions in the lower New York courts ${ }^{10}$ against simple breaches of col-

15. 201 App. Div. 487, 194 N. Y. Supp. 401 (1st Dep't 1922).

16. Nothing in the decree of the lower court indicates that this is a suit to enjoin breach of contract. 117 Misc. 735, 748, 192 N. Y. Supp. 564, 570 (Sup. Ct., 1922).

17. But notice the way in which the agreement is broken down in the lower court to get it to fit the handiest formula. It is treated as a series of agreements between the individual members of the employers' association on the one side and the union on the other. Thus there can be conspiracy by a group of persons and inducement by a third person-the association-to breach the agreement.

18. "The defendants were not required to do anything that they had not agreed to do, nor were they prohibited from doing anything that they had a right to do under the contract." This, of course, is an argument that might be made to justify injunction against breach of any contract.

19. Without attempting to be exhaustive, there have been found at least fifteen sutecessful suits by unions for specific performance or injunction against breach in the lower New York courts from 1928 to 1938 . Mrost of them have come during the last few years. A few particularly deserve a place in any documentary history of American 
lective agreements by employers, but it has also had considerable influence outside of that State. In California, ${ }^{20}$ Georgia, ${ }^{21}$ Massachusetts, ${ }^{\text {,2 }}$ Mississippi, ${ }^{23}$ New Jersey, ${ }^{24}$ Ohio $^{25}$ and Texas, ${ }^{26}$ such injunctions have been issued $^{27}$ with frequent citations of Schlesinger $v$. Quinto. Only in Iowa, ${ }^{2 \mathrm{~N}}$

labor. One of these is Farulla v. Freundlich, 152 Mfisc. 761, 274 N. Y. Supp. 70 (Sup. Ct. 1934), 153 Misc. 738, 277 N. Y. Supp. 47 (Sup. Ct. 1934), 155 Misc. 262, 279 N. Y. Supp. 228 (Sup. Ct. 1935), Matter of Ralph A. Freundlich, Inc., 2 N. L. R. B. 802 (1937) (a successive stage of the fight); Maisel v. Sigman, 123 Misc. 714, 205 N. Y. Supp. 807 (Sup. Ct. 1924) (unsuccessful suit by an employer to set aside a bargain made with a union, noteworthy for its picture of the bargaining process in action). Enforcemerit in equity has been refused in a few cases. Burickson v. Kleen Laundry Service, $242 \mathrm{App}$. Div. 701, 272 N. Y. Supp. 866 (2d Dep't 1934) ; Morrin v. Structural Steel Board of Trade, Inc., 231 App. Div. 673, 248 N. Y. Supp. 273 (1st Dep't 1931) (preliminary relief refused because existence of agreement disputed); De Agostino v. Odeon-Roosevelt Corp., 93 N. Y. L. J. 2523 (App. Div. 1st Dep't 1935) (relief denied on ground state anti-injunction law forbids injunction before hearing).

20. Weber v. Nasser, 286 Pac. 1074 (Cal. App. 1930), appeal dismissed, (question moot) 210 Cal. 607, 292 Pac. 637 (1930). In view of this, the most that can be stid is that the intermediate appellate court's opinion indicates which way the wind is blowing.

21. O'Jay Spread Co. v. Hicks, 195 S. E. 564 (Ga. 1938) (representative suit by employees to enjoin violation of collective agreement held not subject to general demurrer).

22. Pearlman v. Millman, 7 Law and Labor 286 (Super. Ct. Suffolk Co., Mass. 1925) ; Henry v. Century Shoe Co., 12 Law and Labor 7 (Super. Ct. Essex Co, Mass. 1930). But cf. Ryan v. Tuttle-Jones Co., 3 Law and Labor 139 (Super. Ct. Essex Co., Mass. 1921) ; Goyette v. Watson Co., 245 Mass. 577, 579-80, 581-3, 587-90, 140 N. E. $285,286,287,288-290$ (1923) (enforcement refused either because agreement no longer in existence or, if in existence, because plaintiff union admitted it could not furnish enough men to do the work).

23. Mississippi Theatres Corp. v. Hattiesburg Local Union, No. 615, 174 Miss. 439, 164 So. 887 (1936).

24. Hudson Bus Transportation Drivers' Association v. Hill Bus Co., 121 N. J. Eq. 582, 191 Atl. 763 (1937) (affirmed injunction ordering defendant bus company to employ only union members per agreement). Cf. Adelman v. Universal Fur Dressing Co., 116 N. J. Eq. 511, 174 Ati. 523 (1924).

25. Leveranz v. Cleveland Home Brewing Co., 24 Ohio N. P. (N. S.) 193 (1922); Brotherhood of Railway Trainmen v. Pennsylvania Greyhound Lines, 2 L. R, R. 837 (C. P., 1938). In the earlier of these cases there was a charge, which obviously impressed the court, that the defendant employers "conspired" to break their agreements-i.e., that they concertedly did so. Sum v. Independent Retail Fruit Merchants' Association, 144 MIisc. 684, 258 N. Y. Supp. 609 (Sup. Ct. 1932), indicates that a similar charge was equially effective in New York. Compare with Delaware, Lackawanna \& Western R. R. v. Switchmen's Union, 158 Fed. 541, 543 (C. C. W. D. N. Y. 1907), note 48 infra, on "conspiracy" among union members to break the union's side of a bargain.

26. Harper v. Local 520, International Brotherhood of Electrical Workers, 485 S. W. (2d) 1033 (Tex. Civ. App. 1933).

27. See also, e.g., Wetzel v. Clise, 148 Wash. 75, 268 Pac. 161 (1928) (union granted injunction against continued use of union label contra employer's agreement to give it up after termination of bargain).

28. Wilson v. Airline Coal Co., 215 Iowa 855,246 N. W. 753 (1933). 
- Michigan ${ }^{29}$ and West Virginia ${ }^{30}$ has an opposite result been reached by the courts. ${ }^{31}$ The objections raised to enforcement in equity have become pretty well standardized. The Iowa case serves as a good illustration. Lack of consideration to support the agreement, absence of mutuality and equity's timidity in dealing with personal service contracts are those which were found compelling in this case. ${ }^{32}$ Though the court could have planted itself squarely and solely on lack of consideration as its reason for refusing enforcement, ${ }^{33}$ it chose also to throw in some ambiguous words on mutuality and, although the suit was merely to compel the defendant to pay the wages set out in the agreement, devoted a paragraph to the personal service rule.

29. Cases in 4 LAw AND LABOR 216 (1922), cited supra note 10. But cf. Mfecher v. Ellis, 6 Law and Labor 249 (Mich. Cir. Ct., 1924).

30. Berkhammer v. The Cleveland \& Morgantown Coal Co., 8 Law Aad Laron 217 (W. Va. Cir. Ct. 1926).

31. The statement applies only to cases in which the "essential validity" of the agreement or the appropriateness of the remedy asked for have been under discussion. It does not apply to cases in which relief has been refused beenuse of illegality in the agreement or because of the application of the clean hands rule. On these matters see notes $52 \mathrm{ff} ., 57 \mathrm{ff}$. infra. Nor does it apply to such a case as Bulkin v. Saclis, 31 D. \& C. 501 (Pa. C. P. 1938) in which such a suit has been held to fall within a loeal anti-injunetion statute, thus barring relief until the union had attempted extra-judicial remedies first.

32. These and similar defenses have been used in suits brought by an individual on the collective agreements, e.g., (1) There is an adequate remedy at law, hence cquitable relief is not available: Mosshamer v. Wabash Railway Co., 221 Mich. 407, 411, 191 N. W. 210, 211 (1922) (seniority). Contra: Brotherhood of Locomotive Engineers v. Mills, 43 Ariz. 379, 401, 31 P. (2d) 971, 978 (1931). (2) The personal service rule prevents recovery in equity: Chambers v. Davis, 128 Miss. 613, 91 So. 346 (1922) (employer merely a formal party). Contra: Brotherhood of Locomotive Engineers v. Mills, supra at 405,31 P. (2d) 979. (3) The contract of employment is "unilateral" or "lacling in mutuality," (i.e., in many cases, "without consideration") : St. Louis, Iron Mountain \& So. Ry. v. Matthews, 64 Ark. 398, 406, 42 S. W. 902, 904 (1897) (wrongiul discharge); St. Louis, Brownsville \& Afexico Ry. v.-Booker, 5 S. IW. (2d) 856,859 (Tex. Civ. App. 1929), cert. denied, 279 U. S. 852 (1929). Contra: McGlohn v. Gulf \& S. I. R. R., 179 Miss. 396, 403, 174 So. 250, 253 (1937). (4) Another remedy is provided in the agreement which plaintiff has failed to pursue or which, having been pursued, forecleses judicial action: Reed v. St. Louis Southwestern R. R., 95 S. W. (2d) 8S7, 8\&S (MFo. App. 1936) (wrongful discharge). Contra: Rentschler v. Afissouri Pacific Railway Co., 126 Neb. 493, 253 N. W. 694 (1934). (5) Miscellaneous objections: Elmore v. Atlantic Coast Line R. R., 191 N. C. 182, 131 S. E. 633 (1926) (wrong form of action, tort, chosen); St. Clair v. Chicago, MI., St. P. \& P.R. R., 76 F. (2d) 70 (C. C. A. 7th, 1935) (delay in hearing caused by employee precludes him from claiming wages for wrongful discharge).

See note 130, infra. On the general subject of seniority rights, see Christenson, Scniority Rights Under Labor Union Working Agreements, (1937) 11 TEasfLe L. Q. 355; Comment, Seniority Rights in Labor Relations (1937) 47 YALE L. J. 73.

33. The text of the agreement read:

"Agreesient, Aug. 18, 1931.

"It is agreed between District No. 13, U. M. W. of A., and the Airline Coal Company of Ottumwa, Iowa, that the above Coal company shall pay the wage scale as specified and operate under the terms 
Granting that the objection to enforcing the agreement for lack of . consideration was well taken in the Iowa case, what of the other objections? The requirement that there be mutuality of remedy as well as mutuality of obligation as a condition precedent to equitable relief has been so fully and completely criticized that it needs little comment here. ${ }^{34}$ Professor Simpson has seen in these collective bargaining cases a tendency to reject the rule. ${ }^{35}$ This is a permissible interpretation, particularly in jurisdictions where the rule has been weakened in other types of cases. It is equally possible, however, that these cases will be used in the future as a justification for giving an employer equitable relief against a defaulting union where such relief would not now be given. ${ }^{36}$

The rule against compelling specific performance of an agreement for personal services is at first glance rather more embarrassing. It has dissolved easily, however, in the hands of courts friendly towards collective agreements. They have got around it by taking a sensible distinction between an agreement to hire a particular person or persons and an agreement to hire unspecified persons from a specified group. In effect they have enunciated a "lump of labor" doctrine, saying, for instance, that "it is the service of a mass of employees" that is involved and that "if one [employee] is unsuitable and incompetent, then the union is prepared to furnish another who is satisfactory." 37

The outcome would presumably be different if there were an agreement by the employer to take those particular employees which were fur-

and conditions of the Des Moines agreement which expires April 1, 1933. Frank Wilson, President, U. M. W. of A. Airline Coal Co., by J. H. Genochio."

The consideration question has not been strongly urged in many cases and the objcction to lack of consideration can be easily obviated by most unions-c.g., granting the use of the union label, promising not to strike, agreeing to furnish workers to the extent of the union's available membership. See Farulla -v. Freundlich, 155 Misc. 262, 265, 279 N. Y. Supp. 228, 232 (Sup. Ct. 1935) (calling off strike). Apart from the reluctance of courts to grant equitable relief against breach of an agreement under seal and the added difficulties which would attend suit on such a contract by members of the union individually, there is no reason why, in jurisdictions in which seal retains its former efficacy, it should not be used. See, e.g., Barzilay v. Lowenthal, 134 App. Div. 502, 119 N. Y. Supp. 612 (1st Dep't 1904). Similarly as to agreements made in conformity with the Uniform Written Obligations Act, in force in Pennsylvania.

34. Walsh, EQuity (1930) c. 14; Restatenent, Contracts \$372; Cook, The Present Status of the "Lack of Mutuality" Rule (1927) 36 YALE L. J. 897; Durfec, Mutuality in Specific Performance (1922) 20 Mrch. L. Rev. 289; Stone, The "Muluality" Rule in New York (1916) 16 CoL. L. Rev. 443. But of. Hanburx, Modern E@uity (2d ed. 1937) 531.

35. Fifty Years of American Equity (1936) $50 \mathrm{HARv}$ L. Rev. 171, 201.

36. See Harper v. Local Union No. 120, 485 S. W. (2d) 1033, 1040 (Tex. Civ. App. 1932); see Maisel v. Sigman, 123 Misc. 714, 730, 205 N. Y. Supp. 807, 820 (Sup. Ct. 1924).

37. Mississippi Theatres Corp. v. Hattiesburg Local Union, 174 Miss. 439, 448, 164 So. 887,890 (1936). 
nished and selected by the union. ${ }^{38} \mathrm{~A}$ decree of specific performance of such an agreement would be a considerable modification of the personal service rule as it is usually stated. Yet such in effect has been the result reached by the Mississippi Supreme Court ${ }^{39}$ and such in effect is the result of the enforcement of the National Labor Relations Act when the Board orders employers to take back men discharged for union activities. The orders of the Board ignore a doctrine that would otherwise thwart the purpose of the Act. Under them the employer is required to accept specific performance of services in order effectively to preserve the employees' right to choose their union affiliations and to bargain collectively. It may be that experience under the Act will lead equity to reconsider its own rule. For the presumption lying behind the rule is that the defendant will require more supervision than a court of equity can give him, that he will be an unwilling and recalcitrant employer or employee. To the extent that this is the rationale, continued refusal to grant specific performance of personal service contracts against an employer is another instance of the imperfect adjustment of legal doctrine to an industrial society. Though technological change and the growth of the corporate employer do not make the employee work in any less personal sense than he used to, they do warrant inquiry into the weight to be given to the "unwillingness" of the modern corporate employer and they necessitate shifting one's eyes from the corporation to the employee's immediate associates and superiors. It is here that experience under the National Labor Relations Act will be very helpful in assessing the worth of the equity rule. If, in fact, the Board's requiring the employer to rehire a man does not disrupt the plant-if, in fact, though the corporate employer is unwilling, the employee's more immediate associates do not refuse to get along with him-the argument in favor of the modification will be impressive. This does not mean, of course, that specific performance will be ordered in every case in which a contract of employment has been broken. Rather the problem for equity will become one of the adequacy of the remedy at law-granting that the adequacy rule itself remains intact. In the case of an individual or a small group, damages may often be an adequate remedy where in the case of a closed shop provision in a collective agreement sued on by the union they would be inadequate.

These cases in which equitable relief has been refused to the union suggest another problem of some importance, ciz., the measure of damages when an action at law is brought by the union-a subject hardly yet touched by the courts. ${ }^{40}$ Punitive damages, it may be taken for granted,

38. Cf. Chinese American Restaurant v. Finegan, 272 Mass. 360, 172 N. E. 510 (1930) (no injunction against union's interference with previous contract whereby collective agreement union was to supply stipulated number of musicians).

39. See note 23 , supra.

40. See Stone Cleaning \& Pointing Union v. Russell, 38 Alisc. 513, 77 N. Y. Supp. 1049 (Sup. Ct. 1902). The presumption in most cases is, apparently, that the union is 
are out of the question. Compensatory damages, as the term is ordinarily used, may well lead to highly undesirable results if used as a measure of maximum recovery. What is needed in addition is a measure that will as effectively fulfill the purposes of the collective bargain as the compensatory standard fulfills the purposes of commercial contracts. If, as has been argued, the agreement is intended, in any case, to prevent the employer from profiting by competition among workers at a level below that set by the bargain and further, in many cases, to prevent inter-employer competition at the expense of labor standards rather than by increasing efficiency and reducing other costs, the minimum standard will have to be what may be called a "fulfillment" or "maintenance" standard rather than a compensatory or a punitive standard. So stated, the general rule could be formulated thus: A plaintiff union is entitled to damages at least to the extent that the employer has profited by his breach of the collective agreement and, in addition, to any special damages which it can. show and which are left uncompensated by the recovery under the first part of the rule. Thus, in the case of a breach of the wages provision of the agreement, if suit is not or cannot be maintained by or on behalf of the individual,employees, ${ }^{41}$ the union should be entitled to collect at least the difference between the wages paid and those called for by the terms of the agreement-the amount, that is, that the individual workers could collect if they sued for themselves and that will act as an effective deterrent to further attempts at wage-cutting, not merely the amount which a jury can be convinced (by what must almost necessarily be unsatisfactory evidence) the union has suffered in its collective capacity. If, over and above this, it can show any special damages, these ought also to be awarded. So, too, damages for breach of a closed shop provision ought to be measured by the employer's gain from the breach and, to the extent that these have not already been taken care of, by the losses to the union and to its members from their inability to find work.

Even if this is the rule that ought to apply where a union is suing on the collective bargain, it does not follow that the ordinary measure of damages should be replaced in the case of a breach by the union with

doing something equivalent to selling services over the counter and that the ordinary rules apply. Cf. Goldman v. Cohen, 222 App. Div. 631, 633, 227 N. Y. Supp. 311, 314 (1st Dep't 1928). As to suits brought by a union on behalf of its individual members whose employer has not lived up to the terms of the agreement, see Barth v. Addie Co., 271 N. Y. 31, 2 N. E. (2d) 34 (1936).

41. For discussion of possible difficulties in the individual employce's maintaining his suit on the agreement, see infra $225 \mathrm{ff}$. In some cases the individual will be unwilling, even if able, to sue. That the union, in its collective capacity, will have sustained damages nonetheless is clear without further statement. The rule suggested in the text, regarding, for instance, the wage scale, will yield the same result as if suits were brought by individual employees for breach of the agreement as to them and by the union for breach as to it. 
a consequent suit by the employer. ${ }^{42}$ In a Federal district court case ${ }^{43}$ damages were awarded to a plaintiff employer against incorporated union defendants. The men had refused to work unless they were paid higher wages than those provided for in the collective agreement which also called for preferential hiring of union members so long as they were available. Though the union officers tried to get the men back to work, they refused to go until they had been ordered to do so by a general meeting of the union. Arguing that the agreement lacked consideration because the plaintiff was not bound to send ships to New Orleans to be unloaded and so to give work to the men, and that, in any event, it did not require them to furnish men but merely fixed wages, hours and the conditions to be observed if they did work, the unions sought to escape liability. The court passed by the first of these objections in silence, admitted that there was no obligation in terms in the agreement for the men to work, but awarded damages on the ground that such was the reasonable import of the bargain. The plaintiff asked that the demurrage for the delay be taken as the measure of damages; the court held that "recovery should be confined to what it would have cost for additional wages to unload the ship at the rate demanded,"-in other words, the unavoidable loss caused to the employer by the strike. Whatever the rule to be applied when the union is plaintiff, this seems to be a reasonable result if the measure of damages is itself to serve the purpose for which, presumably, the agreement is made. On the employer's part, the making of such an agreement-so far as it is purposive at all-is usually for the purpose of getting men to work for him at a scale of wages previously agreed on. ${ }^{44}$ Their refusal to work will result in a loss to him which is measurable by his loss of business or by the additional cost of conducting his business during the forbidden strike. There is no necessity. in such a situation, for a departure from the normally applicable rules of compensatory damages.

Likewise, the general desirability of granting equitable relief at the suit of the union does not require that similar relief be granted in the case of a suit by the employer. Damages are more likely to be an adequate

42. No implication is intended in the next few paragraphs that the only possible breach by a union lies in a forbidden strike or in a refusal to arbitrate; these are, however, the only sorts of breach that have come before the courts. Cf. Powers v. Journeyman Bricklayers Union, No. 3, 130 Tenn. 643, 172 S. IV. 284 (1914).

43. Nederlandsch Amerikaansche Stoomvaart Maatschappij [alios Holland-American Line] v. Stevedores' \& Longshoremen's Benevolent Society, 265 Fed. 397 (E. D. La. 1920). For other cases involving actions for damages for breach of contract, see Honor \& Co. v. New Orleans Longshoremen's Union, reported by Rice in (1931) 44 Hass: L. Rev. 572, 602 n. 118 (ct. unnamed, 1909) ; Busch Jewelry Co. v. Optical Workers Union, 2 I. R. R. 633 (N. Y. Sup. Ct. 1938).

44. See Meltzer v. Kaminer, 131 Misc. 813, 814, 227 N. Y. Supp. 459 (Sup. Ct. 1927). 
remedy in the latter case than they would be in the former. And the personal service rule, so far as it is brought into play, retains considerably more vitality and sense here than it does in the employer-defendant case. For employees still work, and specific performance would compel them to work, in a very personal sense. Their unwillingness to be employed is much more likely to have the consequences that the orthodox personal service rule anticipates than is the unwillingness of the employer to employ them. Such considerations as these ought to be of greater influence in determining the law to be applied than the beauty of any artificial symmetry.

So far as the law of the cases goes there is, as might be expected, little uniformity of treatment. The few cases that we have dealing with the enforceability of a promise to arbitrate agree that an order to do so will be issued at the employer's suit. ${ }^{45}$ But most of the cases are concerned with the propriety of granting equitable relief against a strike. Of these, some enjoin the strike itself, ${ }^{46}$ others dodge that issue by enjoining only

45. Amsterdam \& Co. v. Devery, 5 N. Y. S. (2d) 427 (Sup. Ct. 1938) ; Matter of Long Island Daily Press Publishing Co., 99 N. Y. L. J. 2037 (Sup. Ct. 1938). But cf. Matter of Buffalo \& Erie Ry., 250 N. Y. 275, 165 N. E. 291 (1929) ; Matter of Amsterdam Dispatch, 99 N. Y. L. J. 2593, 2 L. R. R. 524 (App. Div. 1st Dep't 1938), holding the New York arbitration statute limited to interpretation of an existing agrcement and not extending to dispute over future terms. Unions have also secured orders compelling employers to arbitrate. Meeker v. Ellis, 6 LAw ANd LAbor 249 (Mich. Cir. Ct. 1924); Matter of Amalgamated Association of Street \& Electric Ry. Employees, 196 App. Div. 206, 188 N. Y. Supp. 353 (3d Dep't 1921) ; Matter of Collective Bargaining Committee of Consumers Biscuit Co., 93 N. Y. L. J. 3352 (Sup. Ct. 1935) ; Matter of Marcus, 3 L. R. R. 21 (N. Y. Sup. Ct. 1938). And see Publishers' Association of New York City v. New York Typographical Union, 168 Misc. 267, 5 N. Y. S. (2d) 847 (Sup. Ct. 1938) (modifying and confirming arbitration award possible to union). But compare Goldstein v. International Ladies Garment Workers Union, $328 \mathrm{~Pa}$. 385, $196 \mathrm{Atl} .43$ (1038) (the Pennsylvania statute does not permit arbitrators to give the equivalent of equitable re. lief, though such would be all right under common law arbitration); Polk v. The Cleveland Ry., 20 Ohio App. 317, 151 N. E. 808 (1925), note 72, infra.

46. Burgess v. Georgia, Florida \& Alabama Ry., 148 Ga. 415, 96 S. E. 864 (1018); Strassel Co. v. Brotherhood of Painters, Local 118, 7 LAw and Labor 118 (Ky. Cir. Ct. 1925) semble; Lynn Shoe Manufacturers' Association v. United Shoe Workers of America, 1 (no. 1) Law and LABOR 7 (Mass. Super. Ct. 1918) semble; All-Metal Lighting Fixture Corp. v. Wilson, 10 LAw and Labor 243, 248 (N. Y. Sup. Ct. 1028) semble; Glen Alden Coal Co. v. Anthracite Miners of Pennsylvania, 29 Luzerne Leg. Reg. 463 (Pa. C. P. 1935) (ordering defendants to call off a strike). In Greatcr City Master Plumbers Association v. Kahme, 98 N. Y. L. J. 954 (Sup. Ct. 1937), the court explained its injunction against striking for higher wages and shorter hours during the term of an agreement which provided a different method for settling disputes thus: "Neither can it be said that an injunction compels the men in the union to return to work. They individually may do so as they see fit. An injunction enjoins the union from calling or continuing a strike in violation of its contractual obligation and doing acts which might be legal were a strike actually in existence." 
the preliminaries to the strike, ${ }^{47}$ and still others refuse equitable relief completely. ${ }^{48}$

The cases so far discussed have all been simple suits to prevent or to recover damages for a breach of the collective agreement. Granting that any breach will give rise to a cause of action to remedy that breach, how serious must the breach be before the other party is entitled to repudiate the agreement? It has been suggested before that the collective agreement is in some ways comparable to a statute. If the agreement is between a single employer and a large group of employees, the obligations which it casts upon the employees take on a good deal of the flavor of duties imposed by a statute, particularly if there has been a dispute within the union ranks as to whether the agreement in question should or should not be accepted. If it is between an employers' association and a union, the same flavor extends to the employers' side as well. The greater the number of individuals bound by the contract, the more likely it is that a breach will occur; the more disparate the group of human beings it seeks to govern, the more likely there is to be an occasional revolt against it. As a tentative suggestion, then, it might be worth considering whether the problems arising from breach and enforcement of a collective bargain are not more readily comparable to those arising out of the breach

47. Meltzer v. Kaminer, 131 Misc 813, 227 N. Y. Supp. 459 (Sup. Ct. 1927); Preble v. Architectural Iron Workers Union, Local No. 63, 260 Ill. App. 435 (1935); Barnes \& Co. v. Berry, 156 Fed. 72 (S. D. Ohio 1907), rec'd on a finding that no trade agreement existed, 157 Fed. 883 (S. D. Ohio 1908), aff'd, 169 Fed. 225 (C. C. A. 6th, 1909). In all three cases it was emphasized that equity could not forbid the quitting of work: individually or by concerted action, but that it could forbid officers from instigating or calling strikes or from taking strike votes. Probably many of the scuble cases in the preceding note would, if the full decree were available, fall into this group. See also Gilchrist Co. v. Metal Polishers, Buffers \& Platers Local Union No. 44, 113 Atl. 320, 1 (no. 6) LAW ANo LABOR 12 (N. J. Ch. 1919) (inferable that the injunction against the union officers is bottomed on a threatened breach of contract); Newell v. Electrical Business Association, 11 Law and LaBor 209 (Ohio C. P. 1928).

48. Foss v. Portland Terminal Co., 287 Fed. 33 (C. C. A. 1st, 1923) (though threatened strike would be violation of collective agreement embodying provisions of the Transportation Act of 1920 for settlement of differences between parties, equitable relief against defendant officers' calling strike pursuant to already-taken vote of men held forbidden by Clayton Act, in absence of showing that strike would be other than peaceful); Delaware, Lackawanna \& Western R. R. v. Switchmen's Union, 158 Fed. 541 (C. C. WV. D. N. Y. 1907) (injunction denied against officers' advising their members on a strike in violation of collective agreement, where strike had already been voted on by membership and needed only president's sanction to go into effect); Nevins, Inc. v. Kasmach, 252 App. Div. 890, 300 N. Y. Supp. 64 (2d Dep't 1937) (injunctive enforcement of alleged agreement not to strike against public policy as declared by Legislature); Lundoff-Biclnnell Co. v. Smith, 24 Ohio App. 294, 156 N. E. 243 (1927) (mandatory decree ordering officers of union to discipline union members who struck in violation of collective agreement denied on ground that court could not enjoin strike directly and ought not to do so in this roundabout fashion). Cf. Barzilay v. Loewenthal, 134 App. Div. 502, 119 N. Y. Supp. (1st Dep't 1904). 
and enforcement of a statute than to the same problems in the case of ordinary commercial contracts-whether, in other words, there is justification for permitting the aggrieved party to consider the bargain off no matter how trivial the breach. Certainly it is within the reasonable expectation of the parties to a trade agreement that not every employer and not every group of union members will, regardless of local conditions, changes in prices and the cost of living, and simple misunderstanding of the terms of the agreement, abide by it strictly at all times. Though the matter has not been discussed in the cases, ${ }^{40}$ the rules covering breach are probably sufficiently elastic to adjust themselves easily to this situaltion. ${ }^{50}$

A second question that arises is this: Admitting that there has been a breach, how great-how serious-a breach is required before either party may resort to self-help? Must the aggrieved side first come to court, or may it take enforcement into its own hands from the outset? In the case of a commercial contract there is not much difficulty with the problem. Where self-help is resorted to, it is generally of a negative variety, a simple refusal to deal with the other party any longer. Except in those comparatively rare instances in which employers are working their plants at top capacity and the union has a virtual monopoly of the supply of highly skilled and essential labor, this is not an available method of forcing compliance with the provisions of a collective bargain.

From the union's point of view at least, a good deal of the practical answer to be given to the question ought to depend on the speed with which the courts function. Granting, for the sake of the argument, that it is more desirable for such disputes to be settled in court than on the picket line, no union can well be expected to rely solely on litigation if there is a long delay in redress while its members are out of work or wages are being cut and while competing employers are being tempted to follow the leader.

The cases on this question are rather few and contradictory. ${ }^{51}$ More frequently they take another form which provides us with a third question:

49. See Zaritsky v. Lish, 95 N. Y. L. J. 346 (Sup. Ct. 1936) in which the defendant employers' association elected to repudiate the agreement after an unauthorized strike and plaintiff-union's refusal to put the men back to work immediately. Stronger is Davis v. Bonn, 16 Misc. 19, 37 N. Y. Supp. 688 (App.Term 1896), suit on a bond given by an employer to guarantee performance of a closed shop agreement. Defendant discharged a man and the union struck. He then hired non-union men. Held: Plaintifts' was the first breach; nothing in the agreement forbade defendant to discharge; plaintiffs were bound by the bargain to furnish what help he needed. For the other side of the picture, also without discussion, see Burgess v. Georgia, Florida \& Alabama Railway Co, 148 Ga. 415, 96 S. E. 864 (1918).

50. See Anson, Contract (Corbin's 5th Am. ed. 1931) 475 ; Restatement, ConTRACTS (1932) $\S \S 274,275$.

51. Jensen v. St. Paul Moving Picture Machine Operators Local Union No. 356, 194 Minn. 58, 259 N. W. 811 (1935) (at most, defendants had a cause of action for 
The collective bargain having been broken in some way by one party, is that party deprived of the benefit of equitable relief against otherwise forbidden acts by the other party? This, it will be recognized, is nothing but the clean hands doctrine stated in question form. It is doubtful whether there is an answer to the problem even for a single jurisdiction, let alone for all jurisdictions. The facts of such cases as we have may be enough to account for an apparent difference of opinion between, for instance, the Wisconsin and the Massachusetts courts. But taling appearances at face value, one would say that the Wisconsin court adheres to the view that breach of a collective agreenent by the employer so soils his hands that equity will give him no help. ${ }^{22}$ and that the Massachusetts court adheres to a contrary view. ${ }^{53}$ Oregon apparently agrees with Mlassachusetts $^{54}$ and the lower New York courts divide on the subject. ${ }^{35}$

The opposite side of the picture is represented by the question of whether breach of the agreement restricts the tactics which the guilty

damages for prior breach of the contract; such cause of action was not a labor dispute within the terms of the State anti-injunction statute; injunction granted against picketing plaintiff's theater; clean hands doctrine apparently not raised as a defense); Maisel v. Sigman, 123 Miss. 714, 205 N. Y. Supp. 807 (Sup. Ct. 1924); compare Xasser v. Musicians' Union of San Francisco County, 12 Law Axd Laros 204 (Super. Ct. San Francisco Co., Cal. 1930) with Bonwit v. Schlesinger, 4 LAw axid Laror 130 (unnamed ct., N. Y. 1922).

52. David Adler \& Sons Co. v. Máaglio, 200 Wis. 153, 228 N. W. 123 (1929).

53. Samuel Hertzig Corp. v. Gibbs, 3 N. E. (2d) 831 (1936); Phelps Publishing Co. v. Frazer, 3 Law and Labor 124 (Mass. Sup. Ct. 1921); Ryan v. Tuttle-Jones Co., 3 LAW AND LABOR 139 (Mass. Super. Ct. 1921). Not to be confused with this situation are Stearns Lumber Co. v. Howlett, 260 Mass. 45, 157 N. E. 82 (1927); Service Wood Heel Co. v. Mackesy, 199 N.E. 400 (Mass. 1936) (cases where the union had a contract with the third party purchaser as to use of only union products; union enjoined from interfering with prior contract between the plaintiff and the third party). On the question of the chronological sequence of the two contracts, compare ChineseAmerican Restaurant v. Finegan, 272 Miss. 360, 172 N. E. 510 (1930). There is no indication that the court considers the defendants' actions malicious inducements to breach a prior contract, although "malice" seems necessary to an employer's liability for inducing an employee to break an agreement with his union not to enter into any individual employment arrangements. New England Wood Heel "Co. v. Nolan, 208 Mass. 191,167 N. E. 323 (1929) ; Nolan v. Farmington Shoe Manufacturing Co.n 25 F. (2d) 906 (D. Mass. 1928). Nor does the court adopt the rule of the Restatement of Contracts, $\$ 576$, that a later contract lnowingly made in derogation of an earlier one is void.

54. Greenfield v. Central Labor Council, 104 Ore. 236, 192 Pac. 783 (1930), 207 Pac. 168 (1922).

55. It is impossible, of course, to say how much weight the fact of plaintiff's breach carried with the court. Taking the cases at face value, they divide thus: (1) proWisconsin: Yahrbloom v. Freedman, 3 Law and Lazor 278 (N. Y. Sup. Ct., 1921): Bonwit v. Schlesinger, 4 LAW AND LAzOR 130 (unnamed ct., N. Y. 1922); Segenield \& Kalin v. Schlesinger, 117 Misc. 731, 193 N. Y. Supp. 128 (Sup. Ct. 1922) ; (2) proMassachusetts: Greenberg v. Berlin, 4 Law and Laror 309 (N. Y. Sup. Ct. 1922); Bolivian Panama Hat Co., Inc. v. Finkelstein, 127 Mfisc. 337, 215 N. Y. Supp. 399 (Sup. C.. 1925). 
party may thereafter employ. Again the cases are few and mean little unless one knows what rules of law would have been applied in the absence of a breach. It may be that breach was merely thrown in, in some of the cases, as a make-weight and that the relief would have been forthcoming even if there had been no agreement to be broken in the first place. But such cases as we have indicate that breach by the union will be taken by the court as a reason for giving relief to the employer which he might not otherwise get. ${ }^{56}$

Illegality as a problem in the collective bargain chiefly centers around the validity of the closed shop agreement. In spite of all the discussion we have had by the courts and in legal literature generally, it cannot be said that the enforceability or unenforceability of such a provision is well settled in more than one or two jurisdictions. The professed doctrine of practically all of the decisions, ${ }^{57}$ however, has been reasonably consistent with the position of the New York Court of Appeals in Jacobs w. Cohch."is

"It would seem as though an employer should be, unquestionably, free to enter into such a contract with his workmen for the conduct of his business, without its being deemed obnoxious upon any ground

56. Phelps Publishing Co. v. Ringler, 3 Law and Lazor 124 (Mass. Sup. Jud. Ct. 1921) ; Sunshine Theatre Corp. v. Ringler, 3 LAw aNd LabOR 260 (Unnamed Ct. N. Y. 1921); Beckerman v. Bakery \& Confectionery Workers International Union, 28 Ohio N. P. (N.S.) 550 (1931); Weiss v. International Bakery \& Confectionery Workers of America, 13 Law and Labor 136 (Ohio C. P. 1931).

57. Des Moines City Ry. Co. v. Amalgamated Association of Street \& Electric Ry. Employees, Division 441, 204 Iowa 1195, 1206, 213 N.W. 264 (1927); Bandler v. Lorberbaum, 91 N. Y. L. J. 650 (Sup. Ct. 1934) ; Farulla v. Freundlich, 152 Misc. 761, 274 N. Y. Supp. 70 (Sup. Ct. 1934) ; Maisel v. Sigman, 123 Misc. 714, 205 N. Y. Supp. 807 (Sup. Ct. 1924) ; DeAgostina v. Parkshire Ridge Amusements, 155 Misc. 518, 278 N. Y. Supp. 622 (Sup. Ct. 1935) ; Polk v. Cleveland Ry. Co., 20 Ohio App. 317, 151 N. E. 808 (1925) ; Harper v. Local Union 520, International Brotherhood of Electrical Workers, 48 S. W. (2d) 1033 (Tex. Civ. App. 1932); see Restatenent, Contilacrs, $\$ 515$, illustrations 18 and 19 . Compare the test in Upholsterers, Carpet \& Linoleum Mechanics International Union, Local No. 76 v. Essex Reed \& Fibre Co., 12 N. J. Misc. 637, 174 Atl. 207 (Ch. 1935) (" . . . the present contract is but part and parcel of an attempt to unionize the whole industry in the metropolitan area and to create a monopoly of labor in that industry. Such a contract is opposed to public policy and is void").

The virtual unanimity with which the courts test legality $v c l$ non by the possible effect on a non-union employee in these cases makes it unnecessary to do more than suggest that there might be other tests-c.g., the effect on the public at large or the effect on employers. The former finds an echo in Curran v. Galen, 152 N. Y. 33, 37, 46 N. E. 297, 298-299 (1897). For a suggestion of the latter see Folsom Engraving Co. v. McNeil, 126 N. E. 479, 480, 235 Mass. 269, 278 (1920).

58. Jacobs v. Cohen, 183 N. Y. 207, 76 N. E. 5 (1905). The case was decided by a divided court after the unanimous opinion in Curran v. Galen, 152 N. Y. 33, 46 N. E. 297 (1897) had been cleared away by a still more divided court in National Prot. Ass'n v. Cummings, 170 N. Y. 315,63 N. E. 369 (1902). See note 66 , infra. 
of public policy. If it might operate to prevent some persons from being employed by the firm, or possibly, from remaining in the firm's employment, this is but an incidental feature. Its restrictions were not of an oppressive nature, operating generally in the community to prevent such craftsmen from obtaining employment and from earning their livelihood .. . . To coerce workmen to become members of the employes' organization through such a contract, is not the allegation of something which the law will, necessarily, regard as contravening public policy."

The stated rule in this type of case being what it is, one might expect to find a reflection of it in those instances in which an individual nonmember of the union sues because he has been deprived of his job or because he cannot find one. The case would be even stronger if it were a rival union that is suing. One would expect that the individual or the rival union would have a strong cause of action if it could be shown that employment opportunity had been substantially ${ }^{53}$ lessened by the enforcement of the closed shop rules. A showing that employment opportunity had not been substantially lessened would probably be a good defense. Except in Connecticut, ${ }^{60}$ however, this test has not been recognized. ${ }^{61}$ Reading the cases on their facts, the line of cleavage nearly everywhere else appears to be between those in which the non-union plaintiff has lost a job he already had because of a closed shop contract ${ }^{62}$

59. I say "substantially" for want of a better term. Between the zero-restraint when no closed shop agreements are in force and the total-restraint when all employers are bound by such agreements-the only two points on the seale that can be definitely located-there is much room for play. An otherwise indefinite term could be made more satisfactory if the court would base its decision on the equality or inequality of the proportion of jobs available to non-union men to the proportion of qualified workers who are non-members. This, of course, would in many cases necessitate a nice inquiry into qualifications for the job. It would also-as do the present cases-require the court to define the area which it considers important. On the latter point, see Local Union No. 65, Amalgamated Sheet Metal Workers' International Alliance v. Nalty, 7 F. (2d) 100 (C. C. A. 6th, 1925) ; Connell v. Stalker, 21 Misc. 609, 48 N. Y. Supp. 77 (App. Term 1897) indicating, in comparable cases, that it is determined by the distance men ordinarily go from their homes to find work,

60. Connors v. Connolly, 86 Conn. 641, 86 Atl. 600 (1913).

61. Cf. Wilson v. Newspaper \& Mail Deliverers' Union, 123 N. J. Eq. 347, 197 Atl. 720 (Ch. 1938). See note 85, infra.

62. Berry v. Donovan, 188 Míass. 353, 74 N. E. 603 (1905); Fairbanlis v. A[cDonald, 219 Mass. 291, 106 N. E. 1000 (1914) (damages and injunction against carrying out closed shop agreement; when plaintiffs applied to defendant union, membership fee raised to punish them for persistence in remaining members of rival union); Shinsly: v. Tracey, 226 Mass. 21, 114 N. E. 956 (1917) (only damages awarded to plaintiff, expelled from union which controls $90 \%$ of the jobs in the city); Lucke v. Clothing Cutters' and Trimmers' Assembly, No. 7507, 77 NId. 396, 26 Atl. 505 (1893) (the court intimates strongly that an agreement by plaintiff's employer to run closed shop is no justification for defendant's having plaintiff, a non-union man fired, even though many of its own members are out of work; also stressed is defendant's unwillingness to 
and those in which he is merely seeking employment which he cannot find because of a similar agreement. ${ }^{33}$ In the former, he has been permitted to recover; in the latter, he has not.

In contrast with these cases stands the recent decision of the New York Court of Appeals in Williams v. Quill. ${ }^{\text {s4 }}$ If its result varies from those reached in other jurisdictions, it also differs-as the other cases themselves differ-from the result that would be expected to flow from an acceptance of the doctrine set out in, say, Jacobs v. Cohen. Attempting to make use of this doctrine, counsel for the plaintiffs in the Quill case conceded:

"that this contract is valid . . . except . . . that, as the defendant employers constitute the main transit and railroad lines in the locality stated, there is by this contract a monopoly created; that is, if only union men are to be employed, the plaintiffs, if they refuse to join the union, will be without employment."

But the argument was rejected by the court which said that :

"this distinction [between a closed shop agreement that does and one that does not monopolize the employer market (?)] is not justified, and that if there be an evil in the monopoly of the labor market in a particular industry by labor organizations it is a matter to be considered by Legislatures and not by the courts, for the reason that there are two sides to the question-the other side being that the labor organizations, through this means of contracting and negotiating, are enabled to strengthen their representative bodies and to effectuate collective bargaining." 65

It is probably not too much to expect that Williams $v$. Quill will in time find its reflection in the direct enforcement cases. If so, it will be a repetition of New York's experience with technically distinguishable cases in the past. $^{\text {.6 }}$

admit him to membership). But.cf. Baker v. Amalgamated Association of Strect \& Electric Railway Employees, Division 268, 6 LAw AND LABOR 104 (Ohio C. P. 1924); Harmon v. United Mine Workers, 166 Ark. 255, 266 S. W. 84 (1924) (employment at will held decisive).

63. Hoban v. Dempsey, 217 Mass. 166, 104 N. E. 717 (1914) (no allegation that jobs lost by operation of the closed shop agreement; injunction denied); Shinsky $v$. O'Neil, 232 Mass. 99, 121 N. E. 790 (1919) (evidence that plaintifi applied for work at three factories and would have been given a job at any one of them except for the closed shop provision). Accord: Underwood v. Texas \& Pacific Railway Co., 178 S. W. 38 (Tex. Civ. App. 1915) ; Reihing v. Local Union No. 52, International Brotherhood of Electrical Workers, 94 N. J. L. 240, 109 Atl. 367 (1920).

64. Williams v. Quill, 277 N. Y. 1, 12 N.E. (2d) 547 (1938).

65. Id., at 9,551 .

66. The history of the New York court's attitude towards closed shop agreements should be a warning against taking too seriously any attempt to analyze the cases merely on their facts or on their procedural set-up in this field. Curran v. Galen, 152 
Similarly, one might expect some weight to be given to the rule which is said to govern direct enforcement of a collective bargain when a court is called on to determine the liability of a union for harmful activities directed toward getting a closed shop agreement. One might expect to find picketing or other pressure methods condemned if a substantial part of a given industry were already tied up with such agreements and one might expect to find them approved-unless the jurisdiction holds them to be bad regardless of their object-if the industry were not already so tied up. But again, except for a rare instance in New Jersey, ${ }^{\circ T}$ the cases do not break along this line. ${ }^{08}$ Whether the suit is brought by an individual employee or a rival union or by an employer, whether it is won or lost, such rationale as there is in this type of case is phrased in terms of the "right" of the employer to run his plant open-shop if he so pleases or in terms of the "right" of the union members to refuse to work except under such conditions as they please. ${ }^{69}$ The rationale, to put it differently, is no more than a description of the result following from enforcement of the decision and the attempted ratio decidendi could better be abbreviated to an admitted fiat.

These two types of cases, of course, are technically distinguishable from that in which we are primarily interested ${ }^{70}$ - the suit to enforce a closed shop agreement directly. While a court which is willing to sanction a strike or other collective activity for a closed shop is hardly likely to refuse to enforce the resulting agreement, it is quite possible that a court which

N. Y. 33, 46 N. E. 297 (1897) (a suit for damages for procuring plaintiff's discharge from his job, with a closed shop agreement between his employer and defendant union interposed as a defense and rejected); National Protective Association v. Cummings, 170 N. Y. 315, 63 N. E. 369 (1902) (threats to strike unless the plaintiffs discharged not enjoinable); Jacobs v. Cohen, 183 N. Y. 207, 76 N. E. 5 (1905); Kissam v. United States Printing Co., 199 N. Y. 76, 92 N. E. 214 (1910); Bossert v. Dhuy, 221 N. Y. 342, 117 N.E. 587 (1917). Compare Auburn Draying Co. v. Wardell, 227 N. Y. 1, 124 N. E. 97 (1919) (Bossert case distinguished by finding boycotting combinstion's membership too wide).

67. Four Plating Co. v. Mako, 122 N. J. Eq. 298, 194 Atl. 53 (1937).

68. Compare the test-again not consistently adhered to-suggested in Folsom Engraving Co. v. McNeil, 235 Mass. 269, 126 N. E. 479 (1920). See note 57, supro.

69. For two illustrations out of the many available, see Kemp v. Division No. 241, 255 I11. 213, 99 N. E. 389 (1912) (suit by individual employees against the union; judgment for defendant) ; Alfred W. Booth \& Brother v. Burgess, 72 N. J. Eq. 181, 65 Atl. 226 (Ch. 1906) (suit by employer against union; judgment for plaintiff).

70. Also to be distinguished are those cases in which suit is brought, generally under an anti-trust statute, against an employers' association and/or a union, the former agreeing to hire only union men, the latter to work only for association members. For examples, see National Fireproofing Co. v. Mlason Builders' Association, 169 Fed. 259 (C. C. A. 2d, 1909) ; Belfi v. United States, 259 Fed. 822 (C. C. A. 3d, 1919); Brescia Construction Co. v. Stone Masons Contractors' Association, 195 App. Div. 647, 187 N. Y. Supp. 77 (1st Dep't 1921) ; American Fur Manufacturers v. Associated Fur Cost \& Trimming Mianufacturers, 161 Misc. 246, 291 N. Y. Supp. 610 (Sup. Ct. 1936), aff'd, 251 App. Div. 708, 296 N. Y. Supp. 1000 (1st Dep't 1937). 
will put every obstacle it can in the way of attaining a closed shop will nevertheless decline to stir up further trouble once it has been written into a collective agreement. This, we have it from the Massachusetts court, is the law of that state. ${ }^{71}$

The direct enforcement cases, however, raise other questions of importance. For instance, conceding arguendo the illegality of the closed shop provision in a particular agreement, what should be the attitude of the court when some other portion of the agreement is brought into question in the courts? The answer that will be given in practice will probably depend on the degree of repugnance the court entertains towards closed shop agreements in particular and on the degree of frienclliness it entertains towards collective bargaining in general. In an Ohio case ${ }^{72}$ the members of court were divided on the severability of the closed shop provision from the remainder of the agreement. The majority, holding it inseverable, refused to enforce an arbitration award made under another section of the agreement. This would seem to be an unnecessary restult even on common law principles-and it was so urged by the minorityunless the court was determined to show its dislike for the illegal provision in every possible way. It may well be doubted whether the decision would be the same today when collective bargaining is fostered, so far as industries engaged in interstate commerce are concerned, by the Federal government. Any court which is zealous to uphold collective bargains generally but which also feels that closed shop provisions ought to be discouraged will probably work its solution out along some such lines as these: (1) If the union or one of its members is suing on the agreement it will inquire whether granting the relief asked for is, in fact, enforcement of the illegal provision and, if it finds that it is not, will disregard it. (2) If the employer is suing on the agreement, it will inquire whether the agreement would have been made at all-i.e., whether the employer's promise to run closed shop was an important part of the consideration for the union's counter-promises which are now being sued on-if the illegal provision had not been included and will deny relief only if it finds that the closed shop provision does attain this status. ${ }^{73}$

Another question will arise when any of the labor relations boards are faced with having to decide whether the refusal of an employer to bargain about a closed shop agreement is an unfair labor practice and the

71. Smith v. Bowen, 232 Mass. 106, 110, 121 N. E. 814, 816 (1919); Shinsky v. O'Neil, 232 Mass. 99, 102, 105, 121 N. E. 790, 791 (1919). Cf. N. L. R. B. v. Lion Shoe Co., 97 F. (2d) 448,457 (C. C. A. 1st, 1938).

72. Polk v. Cleveland Railway Co., 20 Ohio App. 317, 151 N. E. 808 (1925).

73. On the severability of illegal provisions from legal, see Anson, Contracr (Corbin's 5th Am. ed. 1930) 322, 323, particularly the American footnotes; 3 WiLListon, Contracts (1920) $\$ \$ 1779,1780,1782$; Restatement, Contracts (1932) $\S \S 606,607$. 
employer's defense is put squarely on the illegality of such an agreement. ${ }^{74}$ Both the boards and the courts called on to enforce their orders will have, in such a case, a choice of solutions before them: They may decile, if they are addicted to words, that because such an agreement is "illegal" no order to bargain about it should be issued or enforced. Or they may inquire into the nature of the illegality set up as a defense and, finding that it is illegal in the sense only of being unenforceable ${ }^{i 5}$ or, at most, subjecting the union to liability at the suit of a discharged non-union man, decide that it is a fair subject for bargaining. ${ }^{\text {io }}$

74. The National Labor Relations Act leaves the legality of a closed shop agreement where it was before the Act. See the proviso to $\S \$(3)$ and the explanation of it given in the Report of the Senate Coanarittee on Education and Laros, No. 573, 74th Cong. 1st Sess. (1935) 11 (reprinted in Prentice-Hall Labor Law Service, [ 15,311). Most of the State Acts in terms do nothing to change the common law of the jurisdietion. Three of them-Mass. Acts, 1937 , c. $436, \S 8(3)$; N. Y. Laws, 1937, c. 443, $\$ 704(5)$; Utah Laws, 1937, c. 55, $\$ 9(3)$-copy the proviso of the Federal Act practically verbatim; one-Pa. Laws, 1937, No. $294, \S 6(\mathrm{c})$-makes a few apparently insignificant changes; and one-Wis. Laws, 1937, c. 51, as amended Laws, 1937, c. 173, \$111.0S(2)adds a new confusion by providing that "all-union" agreements are valid so far as the Act is concerned if "the employee [affected by the agreement is] eligible to membership" in the union (quaere whether the test of eligibility is meant to be the man or the job).

75. On the issue of whether an agreement must be reduced to writing or not, the Board has insisted that the Act contemplates an "enforceable" agreement. See In the Matter of St. Joseph Stock Yards Co., 2 N. L. R. B. 39 (1936), particularly at 49ff. Quaere whether this will, or ought, to carry over to the question raised in the text. Where the employer has urged that a strike for a closed shop precludes his employees from petitioning the Board, the Board has uniformly held that the benefits of the Act cannot thus be taken away. See In the Matter of Columbian Enameling \& Stamping Co. v. Enameling and Stamping Mill Employees Union, 1 N. L. R. B. 181, 194 (1936); In the Mlatter of Alaska Juneau Gold Mining Co., 2 N. L. R. B. 125, 142 (1936).

76. The closed shop agreement may also raise some pretty conflict of laws problems in the case of the run-away shop and in connection with regional or nation-wide bargaining between a union and groups of employers. Though the problems are suggested by the cases, they have not yet been put in issue. See Lehigh Structural Steel Co. v. Atlantic Smelting \& Refining Co., 92 N. J. Eq. 131, 111 Atl. 297 (1920). On the run-away shop problem in general, see Comment (1936) 36 CoL. L. Rev. 776; Dubinsky v. Blue Dale Dress Co., 162 Misc. 177, 282 N. Y. Supp. 622 (Sup. Ct. 1936); Farulla v. Freundlich, 152 Misc 761, 274 N. Y. Supp. 70 (Sup. Ct. 1934); Goldman v. Cohen, 222 App. Dir. 631, 227 N. Y. Supp. 311 (1st Dep't 1928); Goldman v. Rosenzweig, 10 LAw A:b Laros 207 (N. Y. Sup. Ct. 1928) ; Goldman v. Wile Importing Co., 10 Law Axid Lacon 207 (N. Y. Sup. Ct. 1928); Goldstein v. International Ladies Garment Workers Union, $323 \mathrm{~Pa}$. 385, 196 At1. 43 (1938); David Adler \& Sons v. Mfaglio, 200 Wis. 153, 228 N. W. 123 (1929). The N.L.R.B. has, in a series of cases, condemned moving or threatening to move plants in order to escape the obligation to bargain collectively. Afatter of $S \& K$ Knee Pants Co., 2 N. L. R. B. 940, 946, 951 (1937); Matter of Lion Shoe Co., 2 N.I.R. B. 819, 825 (1937); Matter of Remington Rand, 2 N. L. R. B. 626 (1937); Matter of Ralph A. Freundlich, Inc., 2 N. L. R. B. 802 (1937). 
Apart from the effect which a closed shop provision has on the jobsecurity and job-opportunity of non-members, the collective agreement affects or may affect non-members in another way. If the path marked out from the time of Lamley $v$. Gye to that of the Hitchman case ${ }^{77}$ is to be followed, we may expect that the courts will, at the instance of a union which has a collective bargain with an employer, enjoin the tunion's rivals from inducing the employer to break it. And such has been the result in some of the cases. ${ }^{78}$ It was pointed out above ${ }^{70}$ that this tort was one of the conceptual foundations of Schlesinger v. Quinto. Since then, however, the New York Court of Appeals has apparently decided that, where a collective agreement is at stake,-at least where an agreement to deal only with a given union is at stake-and where the defendant is a union, the outcome of the case shall turn not on the issue of contract or no-contract, not even on the issue of going relationship or no-going relationship, but on whether the means used to induce the breach are within the bounds of fair persuasion. Such seems to have been its position in Stillwell Theatres $v$. Kaplan: $:^{80}$

"We would be departing from established precedents if we upheld this injunction. We would thereby give to one labor union an advantage over another by prohibiting the use of peaceful and honest persuasion in matters of economic and social rivalry. This might strike a death blow to legitimate labor activities. It is not within the province of the courts to restrain conduct which is within the allowable area of economic conflict."

77. Hitchman Coal \& Coke Co. v. Mitchell, 245 U. S. 229 (1917).

78. Tracey v. Osborne, 226 Mass. 25, 114 N. E. 959 (1917); Lovely v. Gill, 245 Mass. 577, 140 N. E. 285 (1923) ; Henke \& Pillot v. Amalgamated Meat Cutters, 109 S.W. (2d) 1083 (Tex. Civ. App. 1937) ; Rosedeer Mining Co. v. Beard, 3 Law and LABor 15 (Alberta Sup. Ct. 1920). Cf. Kinloch Telephone Co. v. Local Union No. 2, International Brotherhood of Electrical Workers, 265 Fed. 312 (E. D. Mo. 1920), rev'd, 275 Fed. 241 (C. C. A. 8th, 1921), cert. devied, 257 U. S. 662 (1922); British Columbia Telephone Co. v. Morrison, 29 B. C. 289 (1921). But cf. Blankienship v. Kaufman, 96 F. (2d) 450 (C. C. A. 7th, 1938); Church Shoe Co. v. Turner, 218 Mo. App. 516, 279 S. W. 232 (1926); The Lundoff-Bicknell Co. v. Smith, 24 Ohio App. 294, 156 N. E. 243 (1927). Compare the employer-plaintiff cases, note 86 infra.

79. See p. 201, supra.

80. 259 N. Y. 405,182 N. E. 63 (1932), cert. devied, 288 U. S. 606 (1932). Accord: J. H. \& S. Theatres, Inc. v. Fay, 260 N. Y. 315,183 N. E. 509 (1932); Buy -Wise Markets v. Winokur, 167 Misc. 235, 2 N. Y. S. (2d) 854 (Sup. Ct. 1938). For samples of injunctions in the pre-Stillwell days, see Michaels v. Hillman, 111 Misc. 284, 181 N. Y. Supp. 165 (Sup. Ct. 1920) ; Pleaters \& Stitchers Association v. Taft, 131 Misc. 506, 227 N. Y. Supp. 185 (Sup. Ct. 1928); Wolchak v. Wiseman, 145 Misc. 268, 277, 259 N. Y. Supp. 225, 234 (Sup. Ct. 1932); cf. Sum v. Independent Retail Fruit Merchants' Association, 144 Misc. 684, 258 N. Y. Supp. 609 (Sup. Ct. 1932). Accord: Hotel, Restaurant \& Soda Fountain Employees Local Union v. Miller, $272 \mathrm{Ky} .466$, 114 S. W. (2d) 501 (1938). 
The way in which the question was presented to the court-it was an application by a group of employers to restrain activities "calculated to induce or cause" them to break their contracts with a rival of the defendant union-may have given the court the opportunity to reach the result it did, ${ }^{81}$ but it seems fairly clear that the outcome would have been the same even if, as in the more usual case, the plaintiff had been the actual promisee of the bargain. ${ }^{82}$

The pressure method employed in the Stillivell case was picketing of the employer's place of business. Other considerations aside, the result of the case is particularly welcome at a time when two national labor unions are fighting each other. So far, at least, as the appeal is to the employer's customers, such picketing is a fair way of informing the public of the dispute and of permitting it to express its sympathy for or antipathy towards one or the other of the rivals. To forbid it would be to hide from the patron information which might influence his choice. Such a result, moreover, implicitly recognizes a solidarity of interest between an employer and his employees. ${ }^{83}$ If loss of customers has been an allowable method in the past for persuading employers to deal with a union, loss of work via loss of customers may be an allowable method for persuading employees to shift their allegiance from one union to another. ${ }^{84}$ The pressure may, in other words, be as much directed towards inducing the employees to become members of another group as it is towards inducing the employer to discharge his workers and to give their jobs to another group. With this turn in outlook, one of the original justifications for pressure on the employer-rivalry for jobs-is forgotten and there is substituted for it an end-the strengthening of the union itself-which is still looked on askance by more conservative courts. But accepting this as a legitimate end, another desideratum, the openness of the union which is putting on the pressure, is suggested. This, in turn, might better be used as a criterion for determining legality z'el non in the case of a closed shop agreement than the test now applied. ${ }^{85}$ Openness

81. See 259 N. Y. 405 , at 412 . For a criticism of this and the Plcalcrs and Stitchers decision, supra note 80, see (1932) 32 CoL. L. REv. 1248.

82. De Agostina v. Holmden, 157 Misc 819, 285 N. Y. Supp. 909 (Sup. Ct. 1935).

83. In many of the more orthodox cases, considerable verbal weight has been given to allegations that the plaintiff's employees were satisfied with the conditions of their work, etc. If such an allegation is anything more than pure make-weight, which is doubtful, the analogy to the situation suggested in the text is a fair one, for the employer is there using his employees' satisfaction as a means of protecting himself from charges of unfairness and the like. For a recent example, see Keith Theatre, Inc. v. Vachon, $134 \mathrm{Me}$ 392, 187 Atl. 692 (1936). But cf. Schuster v. International Association of Machinists, 293 Ill. App. 177, 12 N. E. (2d) 50 (1937).

84. See Nann v. Raimist, 255 N. Y. 307, 309, 174 N. E. 690,691 (1931).

85. Cf. Wilson v. Newspaper \& Mail Deliverers' Union, 123 N. J. Eq. 347, 197 Atl. 720 (Ch. 1938), enjoining closed union from enforcing a closed shop agreement against the employer to the detriment of plaintiff-employee whom it would not admit to member- 
of the union is, in any event, a test which will almost certainly have to be applied if the New York rule is to be continued under the Federal and State Labor Relations Acts. For under these statutes it is not a union that is protected, but the employees' choice of their bargaining agency free from employer interference. Though it is not unarguable that pressure on the employer to fire employees who refuse to join a given union is illegitimate if he has already made an agreement with them through another bargaining agency, ${ }^{86}$ the argument fails to consider that the pressure may be directed not towards making the employer do what he is forbidden to do but towards persuading his employees to do what they are free to do. As in New York where the courts may at once enjoin the employer from breaking a contract with one union and refuse to enjoin another union from calling the public's attention, by picketing, to the unfairness of the employer in refusing to deal with them, ${ }^{87}$ so under the Acts it may be said that the hurt to the employer arising from such picketing is

ship. The half-apologetic position of the Massachusetts court in Hoban v. Dempsey, 217 Mass. 166, 104 N. E. 717 (1914), the more enthusiastic note of the Appellate Division in Mills v. United States Printing Co., 99 App. Div. 605, 91 N. Y. Stupp. 185 (2d Dep't 1904), and the emphasis placed on the refusal of the defendant union to admit now members in such cases as Lucke v. Clothing Cutters' \& Trimmers' Assembly, 77 Md. 396, 26 Atl. 505 (1893) and Fairbanks v. McDonald, 219 Mass. 291, 106 N. E. 1000 (1914) [cf. Reynolds v. Shipping Federation, (1924) 1 Ch. 28 (pointing out the unwillingness of the plaintiff to join the defendant union)] could be used to advantage by a court which felt inclined to go in this direction. The difficulty of applying such a test, however, is persuasive of the desirability of further administrative, rather than curial, power over labor litigation. For citations to prior discussions of the "open union" question, see Magruder, A Half Century of Legal Influence Upon the Development of Collectite Bargaining (1937) 50 HaRv. L. REv. 1071, 1074.

86. See $i d$. at 1107. "But if the strike is to compel the employer to bargain with an organization which, under the decision of the board [N.L.R.B.], he is duty bound not to bargain with, a law-abiding employer would be an unenviable position if he could not get injunctive relief. The statute does not make the strike illegal. But the statute imposes a duty upon the employer, and a strike to compel a person to violate his duty may be held illegal on common law principles."

The lower Federal courts generally hold that as long as the employer has not bargained with a union certified by the National Labor Relations Board the cxistence of an agreement with a union does not change the otherwise applicable rules. Lund v. Woodenware Workers Union, 19 F. Supp. 607 (D. Minn. 1937); Sharpe \& Dohme v. Storage Warehouse Employees Union, 24 F. Supp. 701 (E. D. Pa. 1938); Houston \& North Texas Motor Freight Lines v. International Brotherhood of Teamsters, $24 \mathrm{~F}$. Supp. 619 (W. D. Okla. 1938). But cf. Grace Co. v. Williams, 20 F. Supp. 263, 266 (W. D. Mo. 1937). But after certification the applicable rules are different. Oberman \& Co. v. United Garment Workers, 21 F. Supp. 20 (W. D. Mo. 1937) ; cf. Union Premier Food Stores v. Retail Food Clerks Union, 2 L. R. R. 523, 664 (E. D. Pa. 1938). Compare the cases cited notes 78 ff. supra.

87. This apparent dilemma was foreseen even a few months before the decision in the Stillwell Theatres case. Esco Operating Corp. v. Kaplan, 144 Misc. 646, 647, 258 N. Y. Supp. 303, 305-306 (Sup. Ct. 1932) ; I. J. Fox, Inc. v. Gold, 87 N. Y. L. J. 354 (Sup. Ct. 1932). 
"incidental" to the legitimate object of winning over members from one organization to another through whatever pressure an informed public may bring to bear on them through the employer. ${ }^{88}$

This, however, suggests still another problem: Given a closed shop agreement between the $X$ corporation and the $Y$ union, and given successful pressure by the $Z$ union on the $X$ corporation's employees to abandon the $Y$ union and to join the $Z$ union, will this not leave the $X$ corporation open to a suit for breach of contract by the $Y$ union? ${ }^{30}$ The problem is acutely raised by the conflict in aims of contract law and of the labor relations acts. The acts, as has already been pointed out, deal with a choice of bargaining agencies by the employees. They do not deal, except incidentally, with protecting the interests of unions in agreements made with employers. If they mean what they say, the duty of the employer to bargain with his employees through an agency of their own choosing is a continuous one. Contract law, per contra, runs in terms of two parties who have bound themselves to deal with each other. These two sets of rules will have to be harmonized in some way: employers cannot fairly be subjected to damage suits or to decrees of specific performance by the courts and, at the same time, to orders by the government authorities to cease engaging in unfair labor practices. Granting that there are other ways out, ${ }^{90}$ the best way, it would seem, would be to recognize such closed shop agreements as in force only so long as the contracting union maintains its leadership in the employer's plant, and subject always to an implied condition that if this leadership is lost the union shall have no cause of action against the employer for breach.11

88. Stillwell Theatre v. Kaplan, 259 N. Y. 405, 409, 182 N. E. 63 (1932).

89. Two cases must be distinguished: (1) "erosion", in which the members drift away one by one; here the closed shop agreement will presumably operate automatically to relieve them from their jobs; (2) "avulsion", in which there is a wholesale turnover of members from one union to another. We are only concerned with the latter.

90. E.g., by saying that the union members are bound by their organization's bargain and cannot get out of it by shifting allegiance. This is the attitude of the lower courts where the issue has been presented. MI. \& MI. Woodworking Co. v. Plywood and Veneer Workers Local Union No. 102, 23 F. Supp. 11, 18 (D. Ore. 1938) ; MIason MIanufacturing Co. v. United Furniture Workers, 2 L. R. R. 838 (Cal. Super. Ct. 1938) ; Pennsylvania Labor Relations Board v. Red Star Shoe Repairing Co., 1 Prentice-Hall Labor Service, II 19,531, 2 L. R. R. 317 (Pa. C. P. 1937). Compare World Trading Corp. v. Kolchin, 1 L. R. R. 608 (N. Y. Sup. Ct. 1938) (change of affiliation of union from A. F. of L to C.I.O. does not bar its suing on agreement). The National Labor Relations Bourd has taken the general position suggested in the text. Matter of Pennsylvania Greyhound Lines, 3 N. L. R. B., 622 (1937) ; Mratter of AI. \& AT. Woodworking Co., 6 N. L. R. B., No. 55 (1938). Cf. In the Matter of The Kinnear Manufacturing Co., 4 N. L. R. B., 773 (1938); In the Matter of Northrop Corp., 3 N. L. R. B. 228 (1937).

91. This will be qualified, of course, by the willingness of the Board, State or Federal, to order elections. The prevailing rule of the National Board is not to order an election more often than once a year unless strong cause is shown. Mrost unions are opposed to long term agreements in any event. But with the present strong conllict between two 
A further problem to which attention is invited by the growth of the collective bargaining system is the status of the collective agreement when an employer goes into an insolvency court. It is a problem, not heretofore acute, which may be of considerable importance the next time a wave of business failures hits the country. Its setting is suggested by the situation in In re Mamie Conti Gowns, Incorporated. ${ }^{2}$ The court, immediately after approving a petition for reorganization under $\$ 77 \mathrm{~B}$, was faced with an application by the debtor to be permitted to discard a collective agreement by which it was bound. Pointing out that the agreement had been made after a long dispute in the industry and that the petitioner's great excess of assets over liabilities raised doubts as to whether the whole of the proceeding had not been instituted in an effort to discard the agreement rather than to effect a reorganization as contemplated by the Act, the court disallowed the petition..$^{93}$ To the debtor's claim that the closed shop provision of the agreement ran counter to the statutory prohibition against requiring employees to join or not to join a union, the court's reply was that that objection could be raised only by an employee. Beyond this, however, the petitioner urged that the whole agreement be discarded under the court's authority to order rejection of executory contracts. It was urged particularly that relief under the Act was necessary "because its [the petitioner's] labor expenses, pursuant to the contract, were out of all proportion to its volume of business and that no feasible plan of reorganization providing for a fair prospect of profit in the future can be put forth as long as the contract remains in force." This, too, the court rejected, pointing out that the collective agreement itself provided for reorganizations, leaving the inference that it thought the granting of the application would give the petitioner an unwarranted advantage over its competitors. That it would have given the petitioner this advantage is clear.

Whatever the legal theory of insolvency proceedings may be, they are, in their economic effects, useful as a means of writing off a top-heavy capital structure and of readjusting production costs to changes in the price level. One asks whether this rehabilitation ought also to carry with it permission to compete with lowered labor costs. There are respectable authorities who argue, and there are cogent reasons for believing, that wholesale cuts in the spending power of the lower income groups do not

rival groups, attempts may be made to hamstring a situation by writing an agreement for more than one or a few years. For a statement of policy against judicial sanction of such long term contracts by use of the injunctive power, see De Agostina v. Holmden, 157 Misc. 819, 285 N. Y. Supp. 909 (Sup. Ct. 1935). Courts could find ample precedent in the restraint of trade cases to cut down an agreement to a reasonable time or, preferably, to refuse to enforce it after a reasonable time.

92. 12 F. Supp. 478 (S. D. N. Y. 1935).

93. Cf. the outcome of the petition in bankruptcy filed by Ralph A. Freundlich, Inc., as reported 2 N.L. R. B. 802 (1937). 
aid in making recovery any easier after a depression. A court guided by this belief will reach different results from a court which sees in the collective bargain merely another executory contract.

It may be, of course, that different provisions of the collective bargain will yield to different treatment in the reorganization court. Certainly, so far as a closed shop provision is concerned, there is no reason, except that wages are likely to be lower in an open shop, for giving greater latitude to an insolvent firm than is permitted others. Nor would there seem to be any good reason for permitting seniority provisions, for instance, to go into the discard. And, if the belief set out above is justified, there is good reason for not disrupting the painfully worked out labor standards -wages, hours, and working conditions - contained in such bargains, particularly if they are common throughout an industry. To allow an employer to gain an advantage over his competitors by cutting down wages, increasing hours, or lowering the conditions under which his employees work would be an admission that he is entitled to compete on whatever level he can regardless of the public effect or the social cost of that competition -an admission that a company which cannot stand the gaff even with a devalued plant and deflated liabilities is entitled to make and market its product at lower labor standards than other firms. Such an admission in the case of one firm would be likely to force a similar admission for all of its similarly situated competitors. The bankruptcy of management could lead to the bankruptcy of collective bargaining. One cannot, then, but approve of the court's rejection of the application and inquire whether the law of this case ought not to be written into the law of the land to avoid trouble in the future.

Not all the cases that we have had in the past have turned out so fortunately as did In re Mamie Conti Gorins. ${ }^{\text {g4 }}$ In one instance it has been held that an equity receiver takes over the management free from any duty theretofore cast on the company not to discharge workers without cause and, if demanded, a hearing. ${ }^{95}$ In another, it has been held that though a receiver proceeded to arbitrate a wage dispute as provided in the collective agreement, no suit for back wages could be maintained on the award after all the property, together with all liabilities incurred during receivership, had been turned back to the company, on the ground that neither the collective agreement nor the arbitration award had been adopted

94. Continental Trust Co. of New York v. Toledo, St. Louis \& Kansas City Ry., 59 Fed. 514 (C. C. N. D. Ohio, 1894) (no interference with receiver's discretion in reducing wages unless abused); Thomas v. Cincinnati, New Orleans \& T. P. Ry., 62 Fed. 17 (S. D. Ohio, 1894) ; United States Trust Co. of New York v. Omaha \& St. Louis Ry., 63 Fed. 737 (C. C. S. D. Iowa, 1894). But cf. Waterhouse v. Comer, 55 Fed. 149 (C. C. W. D. Ga. 1893), and compare Ames v. Union Pac. Ry., 62 Fed. 7 (C. C. Neb., 1894) with Dexter v. Union Pac. Ry., 75 Fed. 947 (C. C. Neb., 1896).

95. In re Seattle, Lake Shore \& Eastern Ry., 61 Fed. 541, 542 (C. C. Wash. 1894). 
by the court. ${ }^{96}$ Even administrative rulings and the acts of Congress under which they were made--to pursue an analogy suggested above-have not escaped. Though Mr. Justice Holmes phrased his position cautiously in holding that the Adamson Act's wages and hours provisions did not apply to a railroad in receivership ${ }^{97}$-pointing out that the law had been enacted in great haste, he wrote: "We cannot suppose that it was meant to forbid work being done at a less price than the rates laid down, when both parties to the bargain wished to go on as before and when the circumstances of the road were so exceptional that the lower compensation would not affect the market for labor upon other roads"-his few words on the possibility of a constitutional issue were seized on by inferior courts to justify a refusal to apply similar statutes to other insolvent corporittions. Without considering the matter further, they proceeded on the assumption that to require an insolvent road to pay the wages prescribed by decisions of the Railway Labor Board would constitute a taking of property without due process of law ${ }^{98}$ It may be that under the circumstances prevailing in these cases the decisions were correct. If so, they ought not to be extended carelessly to cases where they are unwarranted. The constitutional question left in the air by Mr. Justice Holmes but seized on as doctrine by these courts should be checked very carefully. It would be particularly disastrous if it should be extended and if, at the same time, there should be a reassertion of a doctrine formerly taught, in dictum at least, that "interference" by strikers with the management of a plant in receivership is a contempt of court. ${ }^{00}$

II.

The quantity of mental luggage that a lawyer carries around with him in order to answer a simple question is sometimes amazing. Perhaps this is the reason for the law's reputation as a learned profession. In point is the discussion raised by the question: Can an individual union

96. Amalgamated Association of Street \& Electric Ry. Employees v. Des Moines City Ry., 14 F. (2d) 836 (C. C. A. Sth, 1926).

97. Fort Smith \& Western Railroad Co. v. Mills, 253 U. S. 206 (1920). It appears that the men employed were willing to work for less than the rates prescribed by the Act. "To break up such a bargain would be at least unjust and impolitic and not at all within the ends that the Adamson Law had in view." Id. at 209.

98. St. Louis Union Trust Co. v. Missouri \& No. Ark. R. R., 270 Fed. 796 (E. D. Ark. 1921) ; Coffee v. Gray, 158 Ga. 218, 122 S. E. 687 (1924), writ of error dismissed for want of jurisdiction, 268 U. S. 680 (1925) ; Birmingham Trust \& Savings Co. v. Atlanta, Birmingham \& A. Ry., 271 Fed. 731, 738 (N. D. Ga. 1921).

99. The cases are reviewed in Nelles, $A$ Strike and Its Legal Consequences-An Examination of the Receivership Precedent for the Labor Injthction (1931) 40 YALE L. J. 507; see (1933) 33 CoL. L. Rev. 882. For a more recent example, see In re Cleveland \& Sandusky Brewing Co., 11 F. Supp. 198 (N. D. Ohio 1935) (injunction against interference with removal of machinery and goods in process from one plant to another during jurisdictional labor dispute granted; Norris-LaGuardia Act held inapplicable). 
member sue on the collective agreement? Were it not for an exaggerated notion of the importance of privity of contract, there would be little difficulty in answering the question. As it is, however, whether as counsel or as court, we have to go through a long rigamarole chock-full of doctrinally persuasive terminology to get a desirable result.

Doctrine aside, the essential problems in deciding whether an individual may sue on a collective agreement are much the same as those involved in deciding whether he may sue under a minimum wage statute which is itself silent on the subject. The proper inquiries are: Was the statute intended, inter alia, for his benefit? Can his benefit, and that of others. be best preserved if we adopt this as one method of enforcing its provisions? Is there any good reason why it should not be enforced in this way?

City of Phoenix v. Drinka'ater ${ }^{100}$ provides us with a line of reasoning that could well be applied to the collective bargaining cases if we were prepared to admit that they are at all comparable in social aim or in doctrinal solution. Here the statute in question required municipal corporations to pay their employees specified wages. It imposed a penalty for failure to pay those wages, but made no provision for a civil action by an individual to collect the wages. Yet the court allowed recovery of the statutory amount by a worker who had accepted less, apparently without protest. $^{101}$ The mere fact of his employment was held to obligate the city to pay him the full statutory amount:

"The statute, it will be seen, has a two-fold purpose. One is to secure to the individual workman a minimum living wage, fixed by law, and the other is to penalize the employer who fails to pay that wage. With both purposes before us, we certainly think that it would be defeating the intent of the Legislature, so far as the first is con-

100. 46 Ariz. 470, 52 P. (2d) 1175 (1935). Cf. Texas \& New Orleans R. R. v. Brotherhood of Ry. \& S. S. Clerks, 33 F. (2d) 13, 16 (C. C. A. 5th, 1929), aff'd, 281 U. S. 548 (1930) ; Rhodes v. New Orleans Great Northern R. R., 129 Ifiss. 78, 94, 91 So. 281, 282 (1922).

101. No issue was raised on this point. Cf. City of Glendale v. Conuat, 46 Ariz 478,52 P. (2d) 1178 (1935) (right not waivable; plaintiff's acceptance of the lower pay without protest did not, under the circumstances, estop him from claiming the difference later). Accord that a statutorily given right of employees to be paid of within a specified number of hours after discharge cannot be waived: Cato v. Grendel Cotton Mills, 132 S. C. 454, 129 S. E. 203 (1924). See Burdette v. Broadview Dairy Co., 123 Wash. 158, 212 Pac. 181 (1923) ; Larsen v. Rice, 100 Wash. 642, 650, 171 Pac. 1037, 1039 (1918) ; Pederson v. Portland, 144 Ore. 437, 24 P. (2d) 1031 (1933) (acceptance and endorsement of pay checks "in full" for all wages due to date does not bar plaintiff from maintaining his action). But cf. Ryan v. City of New York, 177 N. Y. 271, 278. 69 N.E. 599, 600 (1904) with Pitt v. Board of Education, 216 N. Y. 304, 309, 110 N.E. 612, 613 (1915) ; Wright v. State of New York, 223 N. Y. 44, 48, 119 N. E. 83, 84 (1918). See Black Diamond Coal Mining Co. v. Rankin, 170 Tenn. 651, 98 S. W. (2d) 311 (1936); Konode v. Houston Collieries Co., 110 W. Va. 227, 157 S. E. 407 (1931). 
cerned, if we were to hold that the very ones whom the law was intended to protect were helpless to secure that protection, and must satisfy themselves with knowing that somebody had gone to jail or paid a fine for violating the law. Such would, indeed, be a Pyrrhic victory for the workman, consoling perhaps to his feelings, but of very little value in giving to him what the law says he has earned and is due him." 102

Substitute for "legislature" and "statute," "union and employer," and "collective agreement" respectively, eliminate the notion of penalty, and add, what is already implicit in the statute, the notion of preventing competition below the wage level set by it, and the argument fits as well for a collective bargain as it does for an act of the legislature.

If something closer to the contract pattern presented by the collective bargain is called for, there are the cases in which a public contractor, bound by an agreement with the government to pay a specified rate of wages to his employees, is sued by an employee. ${ }^{103}$ And there are the cases which arose while the President's Re-employment Agreement was in force. ${ }^{104}$ In both instances, without much difficulty, the courts generally allowed recovery. Why then all the fuss and bother over permitting a union member to sue on his collective agreement? The answer lies at least partly in verbal difficulties. For attempts to characterize the collective bargain when deciding on the rights and duties of individual enployees and employers under it have not been particularly successful. On the rhetorical level, for instance, are such descriptions as those of Judge Sibley in Yazoo \& Mississippi Valley Railroad $v$. Webb, ${ }^{105}$ in which he stamped it as something which "whether made in an atmosphere of

102. 46 Ariz. 470,472 (1935).

103. Stover v. Winston Brothers Co., 185 Wash. 416, 55 P. (2d) 821 (1936), appeal dismissed for want of a Federal question, 299 U. S. 508 (1936), (1937) 46 YALE L. I. 706; Hearn v. Ralph Sollitt \& Sons Construction Co., 93 S. W. (2d) 551 (Tex. Civ. App. 1936) ; Turney v. J. H. Hillman Co., 112 Ore. 122, 228 Pac. 933 (1924) (such a claim cannot be waived). Such a claim cannot be defeated on a plea of accord and satisfaction by accepting and endorsing pay checks made out "in full" payment for wages. Goebel v. Elliott, 178 Wash. 444, 35 P. (2d) 44 (1934). But cf. United States for use of Johnson v. Morley Construction Co., 17 F. Supp. 378, 390 (W. D. N. Y. 1936); United States for úse of Boucher v. Murphy, 11 F. Supp. 572, 573 (W. D. Mich. 1935); Kutsche \& Co. v. Anderson, 169 Tenn. 98, 83 S. W. (2d) 243 (1935); Kutsche \& Co. v. Keith, 169 Tenn. $399,402,88$ S. W. (2d) 454, 455 (1935).

104. A large number of these cases concerned the allowance of recovery of the difference between wages paid and agreed upon in the President's Re-employment Agreement (an agreement between the President and individual employers). For discussion of whether the P.R. A. was a contract, see Comment (1933) 33 CoL. L. Rev. 1314. But cf. West v. Norcross, 190 Ark. 667, 80 S. W. (2d) 67 (1935) ; McDonald v. Pend Oreille Mines \& Metals Co., 189 Wash. 389, 65 P. (2d) 1250 (1937) (in suit for difference between wages paid and those prescribed by the P. R. A., held, the Agreement was void because of government coercion or duress), (1937) 32 ILL. L. REv. 356.

105. 64 F. (2d) 902,903 (C. C. A. 5th, 1933). 
peace or under the stress of a strike or lockout resembles in many ways a treaty." To the same class belongs M. Duguit's characterization of it as "a law establishing permanent relationship between two social groups, the legal rule according to which the individual contracts between members of these two groups are to be concluded." ${ }^{108}$ Hardly less rhetorical is Judge Sibley's further attempt at delineation- "a mutual general offer to be closed by specific acceptances." 107 As indicating the results which will flow from the presence of a collective bargain these suggestions leave much to be desired, however adequately they may indicate the general outlook or hopes of the writers. The term begins to acquire apparent legal significance when it becomes a custom-a practice which is "certain, general, uniform, and recognized" 108 -or a usage_-"an established method of dealing, adopted in a particular place, or by those engaged in a particular vocation or trade." 103 A New York court suggests two more ideas in one sentence when it calls the agreement "a contract made by his representative for his benefit" 110 - that the individual employee is a party to a contract made on his behalf by the union as agent ${ }^{111}$ and that he is a third party beneficiary of the contract. ${ }^{112}$ Ill fitting though they may be, it is these last three that represent the more common expression of the courts. ${ }^{113}$

These attempts to force a new relationship into old molds could well be criticized at the verbal level. To call a deliberate agreement arrived at after prolonged deliberation, presumably subject to change by the parties' mutual consent, and existing, by its own terms, for a specified period, a "custom" or a "usage," is stretching the terms a bit further than they have heretofore been stretched.11 To call the union an agent for its members raises doubts: What, for instance, is the status of an agent the result of whose negotiations or whose very authority to make

106. (1918) 27 YALE L. J. 753, 765.

107. Yazoo \& Miss. Valley R. R. v. Webb, 64 F. (2d) 902, 903 (C. C. A. 5th, 1933);

Rentschler v. Missouri Pacific Ry., 126 Neb. 493, 500, 253 N. W. 694, 698 (1934).

108. Aulich v. Craigmyle, $248 \mathrm{Ky} .676,681,59 \mathrm{~S}$. W. (2d) 560,562 (1933).

109. Hudson v. Cincinnati, New Orleans \& Tex. Pac. Ry., 152 Ky. 711, 717, 154

S. W. 47, 50 (1913) (quoting an earlier case in the same jurisdiction).

110. Gulla v. Barton, 164 App. Div. 293, 295, 149 N. Y. Supp. 952, 953-954, (3d Dep't 1914).

111. Miueller v. Chicago \& North Western Railway Co., 194 MIinn. 83, 85, 259 N. W. 798, 799 (1935).

112. See McGlohn v. Gulf \& Ship Island Railroad Co., 179 Miss. 396, 407, 174 So. 250, 252 (1937) ; Blum \& Co. v. Landau, 23 Ohio App. 426, 155 N. E. 154 (1926) (does not appear whether plaintiff a union member or not); Volquardsen v. Southern Amusement Co., 156 So. 678, 679 (La. App. 1934).

113. For another doctrine, believed to be in the process of emerging, see infro note 146.

114. For an example in this field of the usual meaning of custom, see United States Daily Publishing Corp. v. Nichols, 39 App. D. C. 34, 32 F. (2d) $\$ 34$ (1929). 
the agreement in the first place may have been voted against by the same "principal" who is now suing on the contract? To designate the member a third party beneficiary - akin to the unborn child named for the promisor or the named beneficiary of a life insurance policy-raises similar questions, for this is a "third party" who may have participated in the making of the agreement, who may have voted against it, who may have asked for a better bargain than the one that was actually made, and who is, in practically every case, a part of the party who made the agreement.

Doubtless sufficient dialectic can make these quibbles seem small. Analogy, if refined and abstract enough, can induce us to believe that a collective agreement in an industry is sufficiently "like" a custom-a something taken for granted as long as it exists, not deliberately made by the person who is now before the court-to be treated as such. Dialectic, if sufficiently refined, can also point out that like Rousseau's perfect democrat the member of the trade union owes his first duty to the will of the majority. $\mathrm{He}$ is at best but one of many in his organization; his individual will has but small part in making a minority into a majority or a majority into a minority. Having abided by the will of the majority, whether that will is his will or not, he is entitled to profit by whatever bargain that will made for him; and this applies to him whether he be treated as a principal represented in the negotiations by the will of the majority or as a third party outside of that will completely.

One need not continue along this line. It is more important to ask what the consequences of adopting one or another of these concepts is, how far they have been adopted as judged by their "normal" consequences, and how far these consequences-assuming them to be spelled out for the collective agreement as they have been for other types of transactionmake it desirable for the courts to adopt one or another, to blend them, or to work out a concept which, if not entirely new, is at least somewhat different from either the pure stuff or the amalgam which may result from these. The words we use may suggest the result in an unsettled situation; they do not dictate it. One must take the formalistic language as descriptive rather than as definitive. The mold is not yet sufficiently set, one may hope, to leave no way of escape.

With this in mind we inquire briefly into the creation of the individtal member's interest. Is it enough for the plaintiff-member to come into court saying "I am a member of the union. My union has an agreement with the defendant that I will not be discharged without a hearing. I have been discharged without a hearing and I want damages," or must he say more? If this collective agreement is to be treated as a custom, it ought to be that no more is required. If the union be his agent, what more can be required unless we are pushed into the field of ostensible and express authority? If he be a third party beneficiary, surely by the law of the cases no more is necessary. 
But how do the cases hold? In the factual tests that they set up, they break into three groups. The cases in one group are in accord with the results that would be expected under the nominally accepted doctrines. ${ }^{115}$ A minority group is in total disagreement with them; they hold that, for the collective bargain to be of effect in an employee-employer suit, something more than mere membership-as, for instance, "acceptance" or "ratification" of the agreement-must be shown."10 The third group, which may in the end turn out to be a false class, appears to be satisfied with a showing that there was an agreement and that the member knew of it. ${ }^{117}$ Its position has been most clearly stated by the Tennessee court : ${ }^{118}$

"... the legal effect of the agreement between the operators and miners is that it became part of and formed the basis of the contract of employment between each operator accepting it and each of his

115. Bell v. Western Ry. of Alabama, 228 Ala. 32S, 331, 335, 153 So. 434, 436, 439 (1934) semble, (collective bargain in issue partly as employer's defense); Mrastell v. Salo, 140 Ark. 408, 215 S. W. 583 (1919) ; Florestano v. Northern Pacific Ry, 198 Minn. 203, 269 N. W. 407 (1936) (collective bargain in issue partly as employer's defense); Gulla v. Barton, 164 App. Div. 293, 149 N. Y. Supp. 952 (3d Dep't 1914); Johnson v. American Ry. Express Co., 163 S. C. 191, 161 S. E. 473 (1931); Beatty v. Chicago, Burlington \& Quincy R. R., 49 Wyo. 22, 32, 52 P. (2d) 404, 407 (1935).

116. The leading case is Burnetta v. Marceline Coal Co., 180 MO. 241, 79 S. W. 136 (1904). The defendant-employer is attempting to use the collective bargain as a defense against plaintiff's claim; perhaps this helped to condition the outcome of the case Other courts seem to be equally reluctant to permit an employer to set up this sort of a defense. The Henry S. Grove, 22 F. (2d) 444 (D. MId. 1922); Ahlquist v. Alaska Portland Packers' Association, 39 F. (2d) 348 (C. C. A. 9th, 1930). Compare the results in those cases in which the bargain prescribes a mode of procedure [supra note 31, and infra note 130 ] or in which the employer as plaintiff relies on a provision of the bargain infra notes $139 \mathrm{ff}$. Compare, also, the results reached by the lower Mlissouri courts, infra note 117.

Cases in accord, doctrinally or on their facts: Hudson v. Cincinnati, New Orleans \& Tex. Pac. Ry., 152 Ky. 711, 154 S. W. 47 (1913) semble, (self-contradictory on whether "ratification" is always required) [With which compare Saulsberry v. Coopers International Union, 147 Ky. 170, 173, 143 S. W. 1018, 1020 (1912)]; Panhandle \& Santa Fe Ry. v. Wilson, 55 S. W. (2d) 216 (Tex. Civ. App. 1932) ; West v. Baltimore \& Ohio R. R., 103 W. Va. 417, 137 S. E. 654 (1927) ; Kessell v. Great Northern Ry., 51 F. (2d) 304 (W. D. Wash. 1931) ; Holland v. London Society of Compositors, 40 T. L R 440 (K. B. 1924) ; Bancroft v. Canadian Pacific Ry., 30 Manitoba 401 (1920).

117. Cf. Moody v. Model Window Glass Co., 145 Ark. 197, 224 S. Wr. 436 (1920) [with which compare MIastell v. Salo, 140 Ark, 408, 215 S. IV. 583 (1919), cited note 115 supra]; Boucher v. Godfrey, 119 Conn. 622, 178 Atl. 655 (1935) (collective bargain in issue partly as employer's defense; not clear that knowledge is required); McCoy $\mathrm{Y}$. St Joseph Belt Ry., 229 Mo. App. 506, 512, 77 S. W. (2d) 175, 179 (1934); Lyons v. St. Joseph Belt Ry., 84 S. W. (2d) 933 (Mo. App. 1935) [with which compare Burnetta v. Marceline Coal Co., 180 Mfo. 241, 79 S. W. 136 (1904), cited note 116 supra]; Cross Miountain Coal Co. v. Ault, 157 Tenn. 461, 9 S. W. (2d) 692 (1923) (an excellent exhibition of willingness to uphold a collective agreement). See Keysaw: v. Dotterweich Brewing Co., 121 App. Div. 58, 59, 105 N. Y. Supp. 562, 563 (4th Dep't 1907).

118. Cross Afountain Coal Co. v. Ault, 157 Tenn. 461, 46S, 9 S. W. (2d) 692, 694 (1928). 
employees, who entered or continued in the service and employment of such employer with knowledge of its execution and in the absence of any express contract between the individual employee and his employer inconsistent with the terms of the agreement."

If these are the results when a member of the union sues on the agreement, what is to be expected if the plaintiff is a non-member? If one consistently held to the "custom" doctrine, the result should be the same whether the plaintiff is member or non-member. So, too, if one adheres to third-party beneficiary teachings, unless one can find words which explicitly exclude him from the class to be benefited or is willing to make an implication to the same effect. But if union is "agent," then must not some showing be made that the outsider has, by his own actions, whether precedent or subsequent to the negotiation of the bargain, authorized or ratified the agreement? It would seem so, though it may be that the employer's hiring him and knowing of the bargain and accepting the benefits of his labor, could be construed as a waiver of a right to assert, when he is sued on it, that it was not in force. ${ }^{110}$ But that seems somewhat doubtful, too.

Again, we inquire into the cases. On the one side there is Young $?$. Canadian Northern Railway ${ }^{120}$ holding, in a wrongful discharge case, that though the employer had treated the plaintiff as if he were within the terms of the collective bargain, such facts were insufficient to establish "contractual liability by the railway company to the appellant." The court said that the treatment could be explained as well by saying that it was "a matter of policy" as by saying that the agreement required it and had become a part of plaintiff's individual contract of employment. ${ }^{121}$

On the other side there is Yazoo \& Mississippi Valley Railroad $"$. Sideboard ${ }^{122}$ which, taking a full-bodied third-party beneficiary position, holds that a Negro employee is entitled to the rate of wages provided for in an agreement between the employer and a white union. The court pointed out that since there was no closed shop provision, the employer

119. For the converse of this, see Boucher v. Godfrey, 119 Conn. 622, 178 At1. 655 (1935).

120. [1931] A. C. 83 (P. C.). See (1932) 26 ILL. L. Rev. 922, 924.

121. In the lower courts ([1929] 4 D. L. R. 452 (Man. K. B.); [1930] 3 D. L, R. 352 (Man. C. A.)) it appears that plaintiff was not only not a member of the thion in question but as an adherent of another group had been actively opposed to it. But cf. Caven v. Canadian Pac. Ry., [1925] 3 D. L. R. 841, 845 (P. C). For further discussion, see [1924] 3 D. L. R. 783 (Alta. S. C.) ; [1925] 1 D. L. R. 122, 132, 139, 148, 155 (Alta. App. Div.).

122. 161 Miss. 4, 133 So. 669 (1931). The rules specifically required the railrond to pay the same wages to Negroes and white men. Id. at 11. See Gregg v. Starlss, 188 Ky. 834, 224 S. W. 459 (1920) ; cf. Yazoo \& Mississippi Valley Railroad v. Webb, 64 F. (2d) 902,904 (C. C. A. 5th, 1933) ; Rowlett v. Louisville \& Nashville R. R., 255 IKy. 691, 75 S. W. (2d) 371 (1934). 
would otherwise have too much incentive to displace union with nonunion men, but that

"With the rate of pay ... fixed and secured to all employees, the inducement, and the only inducement, that would exist to let out union members and let in non-union men, would disappear. Thus the interest of the union members in respect to the rate of pay was substantially tied into or united with that of nonunion men, including colored train employees; and the contract results in this manner to and for the benefit of all of them so far as the rates of pay were concerned; and, being so, appellant as a third party in interest could accept and rely on its benefits in respect to the rate of pay and sue for the same." 123

Such cases as this one, however, assume or find a contract between the principal parties in the background. Suppose there is no such finding or assumption? How, for instance, if there is no consideration to support the employer's promises to the union? Can the employee, member or nonmember, still sue on it? One wonders: If this is a "custom" as to the employee, why not? Hasn't it been precisely in those cases in which the court was unable to find a contract that it looked for "custom"? So it appears. ${ }^{124}$ But if there is no contract between union and employer, then what of the individual who is the union's "principal"? Still there was a holding out by the employer - a holding out on terms suggested by the union-"a general offer to be closed by a specific acceptance." And if the individual be a third-party beneficiary? It looks as though dialectic headed for a result has broken down. He may sue, to be sure, but his suit will be in quantum meruit or some equivalent; certainly he cannot sue on an agreement that isn't.

The tangle of possibilities multiplies if it is supposed that the agreement between union and employer is unenforceable because contra bonos mores or illegal. If, in an individual employee's suit, one treats the unionemployer bargain as a custom one has got to decide whether it is unitary or multiple, whether its provisions, legal and illegal, all run together or can be separated. Underscoring the word "custom" helps one to suppose that they are multiple and severable and, accordingly, that those that are illegal can be forgotten. But if the union was the employee's agent? A decision whether or not the employer promised him that none but union men will be hired has to be made. If he did, the employee's suit is, $c x$ hypothesi, lost. If he did not-that is, if some of the promises run to the individual, while others, including this one, run only to the union-the

123. 161 Miss. $4,16,133$ So. 669,672 (1931).

124. See Hudson v. Cincinnati, New Orleans \& Tex. Pac Ry., $152 \mathrm{Ky} .711,717$, 154 S. W. 47,50 (1913); Aulich v. Craigmyle, $248 \mathrm{Ky} .676,679,59$ S. W. (2d) 560, 561 (1933). 
-result will be otherwise. ${ }^{125}$ And if the employee is treated as a third party beneficiary, the result would seem to be the same as it is in the cases where there is no consideration or a failure of consideration.

The failure of consideration problem may arise if the union breaks its promises. Can a custom thus easily be broken? If a custom can be established by a definite act there is no apparent reason why it cannot be disestablished by an equally definite act. If the latter is true, it would seem that the worker who continues to work in spite of, say, the strike, cannot maintain his suit, unless those cases in which the custom exists regardless of consideration set the precedent to be followed here. The union-as-agent notion breeds an equally nice question. The agent has broken the agreement, the principal has not. Or did the principal promise the employer personally that there would be no strikes? Then the agent's - striking is a breach of the principal's promise even though the principal himself keeps on working while the agent is on strike. Perhaps, in order to make more sense, we had better read it to mean only that the principal will not participate in a strike. But if the employee is a third party, shall he continue to benefit even when the promisor has broken his promise to the promisee? The underlying bargain has been broken; presumably it is gone completely. The analysis would yield a negative answer to the question except for the effect of an analagous situation.

Suppose the employer and the union get together and agree, during the term of the contract, that changes shall be made. The custom has changed, to be sure, but the employee agreed to work according to the terms of the old custom. It might be urged on this ground that he retains his rights in spite of the change. But since in all probability he is employed at will, is not his employment from this day forth in terms of the new custom, that way of doing things that is so well known, so certain, so stable, and so oft-repeated that men are presumed to have contracted with reference to it? Perhaps, but the answer is far from clear. If, however, the employee is principal and the union is agent, we run into still another question, that of the authority of the union to make changes for him. ${ }^{120}$ He denies the authority to make this change, for it works to his detriment. But, as a loyal member of the union, has he not agreed beforehand to acquiesce in anything the majority does? Then perhaps he has agreed though he disagrees, and he has to take the change whether he likes it or not. But the third party beneficiary, it is laid down in case and text, acquires his rights as soon as the underlying agreement comes into existence and nothing can thereafter change them unless-and here is a lovely spot for an implication!-the privilege of changing has been reserved in the first place. So, unless we can spell waiver out of his being a member of the tunion, the employer is still obligated to him even though his organization

125. See Young v. Canadian Northern Ry., [1931] A. C. 83, (P. C.)

126. Cf. Burnetta v. Marceline Coal Co., 180 Mo. 241, 79 S. W. 136 (1904). 
has told the employer to make certain changes against which he now protests. If, however, this third-party beneficiary is not a member of the union, by what doctrinal device can his recovery on the old agreement be circumvented? There is none apparent at first glance unless, as before, the privilege of changing has been reserved or can be found by implication. ${ }^{127}$

But on this question we can check the accuracy of our deductions-or the adequacy of the concepts with which we started, or the degree of seriousness with which these concepts laid down by the courts are entitled to be taken-against a few cases.

Here is the Kentucky court, for instance. ${ }^{128}$ A union member is suing his employer and his union. It appears that he was in the minority when his local asked the railroad-employer if it would not agree to a change in runs. The railroad agreed without any hesitation. Without discussing how, in the first place, the plaintiff acquired his seniority "right" or what sort of a "right" it is that is being disturbed, the court takes the position that the "right" cannot be changed by mere concurrence of the principal parties to the agreement.

"This contention [that plaintiff ought to act like a loyal member of the union; that he is bound by its acts] ignores the fact that such agreements between organizations of employes and their employer are designed primarily for the individual benefit of the members of the organization, and not to place it within the power of the organization to change or modify the contract at its pleasure so as to affect the individual rights of its members theretofore secured by the agreement . . . Their agreements with employers look always to the securing of some right or privilege for their individual members, and the right or privilege so secured by agreement is the individual right of the individual member, and such organization can no more by its arbitrary act deprive that individual member of his right so secured than can any other person. The organization is not the agent of the member for the purpose of waiving any rights he may have, but is only his representative for the limited purpose of securing to him, together with all other members, fair and just wages and good working conditions...

"If the right of seniority may be changed or waived or otherwise dispensed with by the act of a bare majority of an organization to which the one entitled thereto is a member, it would be builded upon a flimsy foundation of sand which might slip from under him at any

127. Boucher v. Godfrey, 119 Conn. 622, 178 Atl. 655 (1935); Franklin v. Pennsylvania-Reading Seashore Lines, 122 N. J. Eq. 205, 193 Atl. 712 (1937) (non-union men affected by changes in the agreement itself or in its interpretation).

128. Piercy v. Louisville \& Nashville Ry., $198 \mathrm{Ky} .477,248$ S. WV. 1042 (1923). Sce Rolandez v. Star Liquor Dealers, 3 L. R. R. 229 (N. Y. Sup. Ct. 1938). 
time by the arbitrary action of the members, possibly to serve their own selfish ends in displacing him." ${ }^{129}$

Taking a contrary position, and possibly using equally and unjustifiably broad language, ${ }^{130}$ is the Massachusetts court $:^{131}$

"The substantial issue is whether the [seniority] rights of the plaintiffs are fixed by the terms of the agreement between the union and the railroad corporation as it stood when the several plaintiffs entered upon their service, interpreted only in the light then available; or whether as the agreements changed from time to time, the modifications and possible changes in interpretation of terms agreed upon by the union and the railroad corporation modified and affected the individual contracts of those already in the corporation's employ. We think the latter to be the proper position. The transaction is an agreement between an employer and a labor union designed by the latter to benefit itself and those members who enter the employer's service. If it modified the agreement with the employer, the employee

129. Perhaps the broad language, apparently applicable to all changes in collective bargains, will be limited to attempted changes in seniority rights. Id. at 1045; Yazoo \& Miss. Valley R. R. v. Mitchell, 173 Miss. 594, 607; 161 So. 860, 861 (1935). By much the same argument as that used in the principal case, it has also been held that where, under a collective bargain provision, the plaintiff lost his seniority by accepting transfer to another department, he could not take advantage of a subsequent change in the agreement striking out this rule. McGregor v. Louisville \& Nashville R. R., $244 \mathrm{Ky}$. 696, 51 S. W. (2d) 953 (1932).

130. For the case may fall in with one of two classes of "changes" which the courts generally uphold, viz., changes arising from "interpretation" of the agreement, and changes necessitated, as in the instant case, by consolidation, merger, and the like in the railroad itself. For examples, see Boucher v. Godfrey, 119 Conn. 622, 178 Atl. 655 (1935) (acquiescence or participation in making the change), Crisler v. Crum, $115 \mathrm{Neb} .375$, 213 N. W. 366 (1927) (failure to exhaust remedies within the union), Burton v. OregonWashington Navigation Co., 148 Ore. 648, 38 P. (2d) 72 (1934) (interpretation of agreement). For the most part in these cases the employer is a nominal party; the true defendant is the union alone.

One of the great advantages-as will be seen by comparing the struggles of the Kentucky court in Gregg v. Starks, $188 \mathrm{Ky} .834,224$ S. W. 459 (1920) and McGregor v. Louisville \& Nashville R. R., $244 \mathrm{Ky} .696,51 \mathrm{~S}$. W. (2d) 953 (1932)-of allowing the union officers to interpret the agreement and give it a practical application is that it avoids all the difficuities of judicial inquiry into highly technical and often tersely worded collective bargains and substitutes for this something approximating an expert commission's interpretation of the same. This has gone so far that in Chicago, Rock Island \& Pacific Ry. v. Sawyer, 176 Okla. 446, 56 P. (2d) 418 (1936) it was held that plaintiff's reliance on defendant's interpretation of the seniority provisions of an agreement between it and the union (of which plaintiff was a member) to the effect that he (plaintiff) would not lose his seniority if he accepted transfer to another job, avails him nothing if the parties (plaintiff and defendant) were mistaken as to its meaning as understood by the union and later agreed to by defendant.

131. Donovan v. Travers, 285 Mass. 167,188 N. E. 705 (1934). See Hartley v. Brotherhood of Railway and Steamship Clerks, 283 Mich. 201, 277 N. W. 885 (1938). 
must acquiesce. In no correct sense is the union an agent. It is a principal ..." "132

These cases suggest a converse problem: May the member-or the non-member-contract out of the provisions of the agreement? If so, what effect will this have on the union's being able to maintain a suit? If we say that the agreement is, for the individual, a custom, surely he can agree to terms other than those there set forth. If we say that he is a third-party beneficiary, the same result will probably follow. If we say that he is a principal and the union an agent, cannot the principal and the other contracting party call off the agreement? Undoubtedly yes, unless, as is extremely unlikely, agency coupled with an interest can be spelled out of the relationship between the union and its members. But the custom may be a contract between the principal parties, the agent may turn out to be a principal if it sues to enforce the agreement itself and the union is clearly entitled to sue if the third party agrees to talie less than the agreement calls for. On the effect on the enforcement of the bargain by the union of a member's agreeing to terms lower than those of the agreement, we have no case law. But on its effect on the member's own suit we do.

The tendency of the cases is pretty clearly in the direction of saying that an inconsistent agreement between employer and employee is no bar to the latter's suing on the collective bargain. Only one decision, however, adopts the rule as a rule. ${ }^{133}$ The others go on the ground that the private bargain was made without knowledge of the collective agreement ${ }^{134}$ or that the quantum of evidence required to show that the inconsistent proposal was accepted by the worker is, apparently, greater than usual. ${ }^{135}$

132. Donovan v. Travers, 285 Mass. 167, 173, 18S N. E. 705, 703 (1934). A good deal of ink has been spilled trying to define the "mature" of seniority rights under collective agreements. See, for instance, Judge Hutcheson's concurring opinion in Estes v. Union Terminal Co., 89 F. (2d) 768, 774 (C. C. A. 5th, 1937). Compare Burger v. McCarthy, 84 W. Va. 697, 100 S. E. 492 (1919) with Gleason v. Thomas, 117 IV. Va. 550, 186 S. E. 304 (1936); cf. McMlurray v. Brotherhood of Railway Trainmen, $50 \mathrm{~F}$. (2d) 968,970 (W. D. Pa. 1931) ; Burton v. Oregon-Washington Navigation Co., 148 Ore. 648, 38 P. (2d) 72 (1934).

133. Reichert v. Quindazzi, 6 N. Y. S. (2d) 284 (MIun. Ct. 1938).

134. Gulla v. Barton, 164 App. Div. 293, 149 N. Y. Supp. 952 (3d Dep't 1914). But cf. Langmade v. Olean Brewing Co., 137 App. Div. 355, 121 N. Y. Supp. 388 (Ath Dep't 1910). There is considerable dictum in the cases-see, e.g., Cross Mountain Cosl Co. v. Ault, 157 Tenn. 461, 468, 9 S. IV. (2d) 692, 694 (1928), cited note 118 suprointimating that explicit employer-employee agreement will prevail over an employerunion contract.

135. Dierschow v. West Suburban Dairies, 275 Ill. App. 355 (1934). But cf. Shuppan v. Peoria Ry. Terminal Co., 30 F. (2d) 569 (C. C. A. 7th, 1929). Compare the results reached on the doctrine of accord and satisfaction in Yazoo \& Mrississippi Valley $R$. v. Sideboard, 161 Miss. 4, 133 So. 669 (1931) and Yazoo \& Mlississippi Valley R. R. v. Webb, 64 F. (2d) .902 (C. C. A. 5th, 1933) (both involving wage disputes) with 
Probably without the aid of statute no better result than that indicated by these latter cases can be worked out. It may be, however, that the rule of the Restatement, holding unenforceable a bargain which is inconsistent with an earlier contract and made with knowledge of the inconsistency, can be put to useful work here, however absurd it may be thought to be as a general proposition. ${ }^{136}$ In any event the analogy to the minimumwage statutes, heretofore stressed, will suggest the desirable restilt to be achieved by the courts, if not the rule of law to be applied. ${ }^{137}$

The discussion so far has turned around the concept of rights accuured by the individual employee under the collective agreement and their modification by agreement between the principal parties to the bargain. Stuppose, however, that the employer is asserting that the individual employee owes him a duty under the agreement. How do the standard doctrines work out here? Custom will probably give the employer the result he wants. So will agency. The only hitch comes with third-party beneficiary doctrine. The third-party is a beneficiary, not an obligor. Unless we can say that his acceptance of the benefits of the agreement carries with it the duties as well, ${ }^{138}$ we run into difficulties.

But there has not, in practice, been much disagreement among the courts on this question. When the Massachusetts court was asked to enjoin a defendant union member from violating a provision in the agreement between the plaintiff-former employer and the union that men leaving plaintiff's employ would not work for a competitor, or for themselves as competitors during the next 90 days, it announced, without an attempt to spin out doctrine, that defendant, having been familiar with the agreement and having been employed by plaintiff as a union member, was bound by this term of the agreement. ${ }^{130}$ A New York court took the same conclusion for granted, after defendant admitted that the contract between plaintiff and the union had been made, that he was a member of the organization, and that he had the duty, if any, cast on him by the

the "non-waiver" teaching of the Missouri court in McCoy v. St. Joseph Belt Ry., 229 Mo. App. 506, 77 S. W. (2d) 175 (1934).

136. Restatearent, Contracts (1932) $\$ 576 ; 6$ Williston, Contracts (rev. cd. 1938) \$1738; Lauterpacht, Contracts to Break a Contract (1936) 52 LAw Q. REv. 494.

137. On the supersession of an employer-employee bargain by the union-employer agreement, see Strobe v. Netherland Co., 245 App. Div. 573, 283 N. Y. Supp. 246 (4th Dep't 1935); Individual Damp Wash Laundry Co. v. Meyers, 2 L. R. R. 162 (Ohio C. P. 1938).

138. Not to be confused is the situation in Flyum v. Alaska Packers' Association, 5 Alaska 200 (1914) where plaintiff sued in quantum meruit, measured by terms of collective agreement, for work done in absence of another. Held: "Plaintiff . . . was not a party to this [agreement], and was not bound by its terms, nor can he come in under its terms, claiming its benefits, while refusing to recognize its obligations, on his part to be performed"; plaintiff takes only what he agreed to accept under his individual contract.

139. Whiting Milk Co. v. Grondin, 282 Mass. 41, 184 N. E. 379 (1933). 
agreement. ${ }^{140}$ The same was true in a Pennsylvania case in which the defendant employer, sued for wages, sought to withhold an amount equal to the "fine" of a dollar a day provided in the bargain for the event of an unauthorized strike. ${ }^{141}$ Different, it seems, is the position of a nonunion member, for the Kentucky court has held in Gregg $\%$. Starks ${ }^{1+2}$ that, since he was not a party to an agreement between a railroad and the union to arbitrate differences, he could not be bound by the arbitration award.

None of these is a strong case; most appear to be simple assertions by the court without issue raised. A more difficult problem comes in deciding whether the burdens of the agreement can be got rid of by resignation from an employers' association or from a union and whether, by a similar resignation, rights are lost. Customs go on willy-nilly and withdrawal might be expected to make no difference. If the agency be a continuing one-a series of acts constructively repeated day after day and week after week-resignation might divest the member of his rights and duties; but if the work of the agent was an act done once and for all, there would be no such effect. And the third-party beneficiary, if he would have come within the terms of the agreement without having been a member in the first place, would presumably continue to be such even after he had resigned. Contrariwise, if membership was a prerequisite to inclusion within the terms of the agreement, his subsequent withdrawal would make a difference. Most of the cases that have considered the matter allow this mode of escape, ${ }^{143}$ but the recent swing appears to be in the other direction. ${ }^{144}$

We have; finally, one other question: It is to be noticed that suits brought by individual employees under collective agreements have centered around three problems exclusively-wages, seniority and wrongful discharge. Is this to be taken to mean that these, and similar, questions are the only ones that may be litigated by the individual or does it mean

140. Eastchester Cleaners v. Platek, 95 N. Y. L. J. 2438 (Sup. Ct. 1936). Accord: Western-United Dairy Co. and Milk Wagon Drivers' Union v. Nash, 293 Ill. App. 162, 12 N. E. (2d) 47 (1938). For the same assumption or finding, as to employers who were members of associations with which plaintiff unions had trade agreements, see Dubinsky v. Blue Dale Dress Co., 162 Misc. 177, 178, 282 N. Y. Supp. 622, 623 (Sup. Ct. 1936) ; Maisel v. Sigman, 123 Misc. 714, 718, 205 N. Y. Supp. 807, 809 (Sup. Ct. 1924).

141. Henderson v. The Cambria Smokeless Coal Co, 20 D. \& C. 654 (C. P. 1934). Compare the use of the collective bargain as a defense by the employer, notes 115,117 supra.

142. Gregg v. Starks, 188 Ky. 834, 838; 224 S. W. 459, 460 (1920).

143. Gary v. Central of Georgia Ry., 37 Ga. App. 744, 141 S. E $\$ 19$ (1928) ; Ryan v. Tuttle-Jones Co., 3 Law and Labor 139 (Mrass. Super. Ct. 1921); Blagg Co. v. Rettig, 24 Ohio N. P. (N.s.) 546 (1923).

144. Supra note 90. Cf. United Electric Coal Co. v. Rice, 80 F. (2d) 1 (C. C.A. 7th, 1935), cert. denied, 297 U. S. 714 (1936). 
merely that they are the only ones that have been so litigated? To put it another way, may the individual sue on the collective agreement to protect any interest that by any possibility may accrue to him under the agreement, or does enforcement of some provisions belong to the union exclusively? May the individual, for instance, sue to enjoin breach of an agreement to run closed shop, or does that privilege to sue belong to the union? Conversely, if the individual sues for wages-more strongly, if a number of individuals, sue for wages-may the union organization agree with the employer to waive this portion of the bargain? One can imagine instances where the union might well be justified in making some arrangement even after the individual's asserted "rights" had accrued to him; one can also imagine instances in which a perverse or lackadaisical union leadership, solidly entrenched, would fail to assert proper claims against the employer to the detriment of the union membership. The answer to this sort of question is yet to be found. But the analysis we have already gone through makes it clear that no satisfactory solution lies in the question-begging assertion of the Louisiana court ${ }^{145}$ that

"The plaintiff is limited to an enforcement of his individual rights under the contract. He cannot champion the rights of the local union as a whole."

Probably the answer was a good one in the particular instance. Probably also the solution lies in a working out of some trade union equivalent to the stockholder's suit in corporate law. In any event the solution, if there is any and whatever it is, lies in the future.

We come, then, practically to the point at which we started. To attempt to write about or to state "the law of the collective bargain" as it applies to the individual employee is to attempt to write about or to state something which does not exist. True, there are cases, perhaps a hundred or so all told. But there is no body of doctrine, in any sense of the word, to which reference can be made to predict the outcome of as yet unsettled questions. It can hardly even be said that there are standards, let alone a frame, of reference. We are still engaged, in this domain of enforcement of individual rights and duties under the agreement, in threshing out even the barest fundamentals of law. Older cases carry little weight and the meaning of new ones, for lack of a context, is indeterminate. A particular point here and there is being "settled," but how long it will remain settled is still to be seen. No well thought out line of attack, such as existed fifteen or twenty years ago when Walter Gordon Merritt and a flourishing League for Industrial Rights were engaged in developing a vast body of legal obstacles to labor's ambitions, exhibits itself in the cases either from labor's side or from that of the employer. Rather we

145. Volquardsen v. Southern Amusement Co., 156 So. 678 (La. App. 1934). 
have what is assumed to be the proper method for developing a common law on any subject-cases coming haphazardly to the courts, counsel changing from case to case, no firm assertion, no iteration and reiteration, of "principles" which, even in our stage of the game, will have to be threshed out if there is to be certainty under collective bargaining. Presumably we have got beyond the stage of arguing whether collective agreements ought to be enforced at law. But we have not got far beyond it. Verbalisms abound and old formulae are turned to or ignored as seems best at the moment. Perhaps the Massachusetts court, seeming to ignore the words that other courts resort to-"custom", "agent", "third party beneficiary"-is taking the wiser course in choosing a comparatively new and untainted word-"member"146-and filling it up with content as the cases come. Deliberately chosen or not, consciously or unconsciously, some such route as this will have to be, and is being, followed by the other courts as well. And this, I take it, is the common law equivalent of M. Duguit's warning to the French legislators of twenty years ago:

"The truth is that although collective labor contracts have multiplied ... the time has not yet come for legislative action. We have here an institution which is still in the process of formation and is far from its complete development." 147

146. Donovan v. Travers, 285 Mass. 167, 188 N. E. 705 (1934); Whiting Mifils Co. v. Grondin, 282 Mass. 41, 184 N. E. 379 (1933).

147. Supra note 1 , at 766 . 